\title{
Data report: raw and normalized elemental data along the Site U1338 splice from X-ray fluorescence scanning ${ }^{1}$
}

\author{
Mitchell Lyle, ${ }^{2}$ Annette Olivarez Lyle, Thomas Gorgas, ${ }^{3}$ Ann Holbourn, ${ }^{4}$ Thomas Westerhold, ${ }^{5}$ \\ Ed Hathorne, ${ }^{6}$ Katsunori Kimoto, ${ }^{7}$ and Shinya Yamamoto ${ }^{8}$
}

\section{Chapter contents}

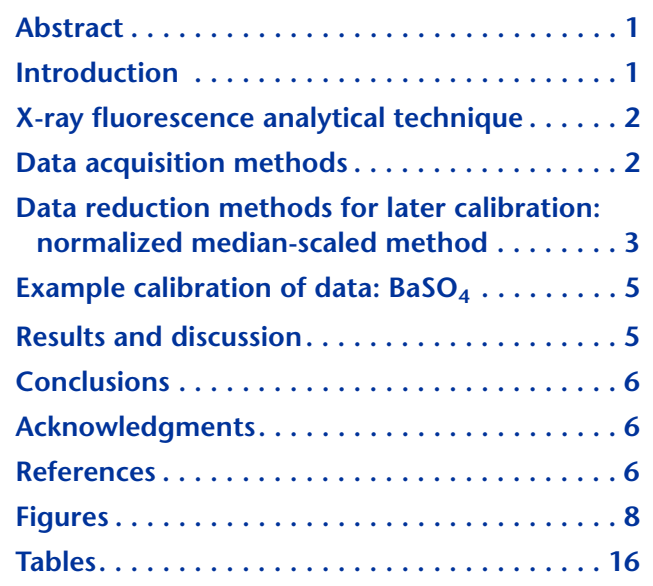

'Lyle, M., Olivarez Lyle, A., Gorgas, T., Holbourn, A., Westerhold, T., Hathorne, E., Kimoto, K., and Yamamoto, S., 2012. Data report: raw and normalized elemental data along the Site U1338 splice from X-ray fluorescence scanning. In Pälike, H., Lyle, M., Nishi, H., Raffi, I., Gamage, K., Klaus, A., and the Expedition 320/321 Scientists, Proc. IODP, 320/321: Tokyo (Integrated Ocean Drilling Program Management International, Inc.). doi:10.2204/iodp.proc.320321.203.2012

${ }^{2}$ Department of Oceanography, Texas A\&M University, College Station TX 77843, USA.

Correspondence author: mlyle@ocean.tamu.edu ${ }^{3}$ Integrated Ocean Drilling Program, Texas A\&M University, 1000 Discovery Drive, College Station TX 77845-9547, USA.

${ }^{4}$ Institut für Geowissenschaften, Christian-

Albrechts-Universität zu Kiel, Olhausenstrasse 40, 24098 Kiel, Germany.

${ }^{5}$ Center for Marine Environmental Sciences (MARUM), University of Bremen, PO Box 330440, 28334 Bremen, Germany.

${ }^{6}$ IFM-GEOMAR, Leibniz Institute of Marine Sciences at University of Kiel, Wischhofstrasse 1-3, D-24148 Kiel, Germany.

${ }^{7}$ Institute of Observational Research for Global Change (IORGC), Japan Agency for Marine-Earth Science and Technology, 2-15 Natsushima-Cho, Yokosuka 237-0061, Japan.

${ }^{8}$ Institute of Low Temperature Science, Hokkaido University, N19W8, Kita-Ku, Sapporo 060-0819, Japan.

\section{Abstract}

We used X-ray fluorescence (XRF) scanning on Site U1338 sediments from Integrated Ocean Drilling Program Expedition 321 to measure sediment geochemical compositions at $2.5 \mathrm{~cm}$ resolution for the $450 \mathrm{~m}$ of the Site U1338 spliced sediment column. This spatial resolution is equivalent to $\sim 2 \mathrm{k}$.y. age sampling in the $0-5$ Ma section and $\sim 1$ k.y. resolution from 5 to $17 \mathrm{Ma}$. Here we report the data and describe data acquisition conditions to measure $\mathrm{Al}$, $\mathrm{Si}, \mathrm{K}, \mathrm{Ca}, \mathrm{Ti}, \mathrm{Fe}, \mathrm{Mn}$, and $\mathrm{Ba}$ in the solid phase. We also describe a method to convert the data from volume-based raw XRF scan data to a normalized mass measurement ready for calibration by other geochemical methods. Both the raw and normalized data are reported along the Site U1338 splice.

\section{Introduction}

A primary objective of the Integrated Ocean Drilling Program (IODP) Pacific Equatorial Age Transect (PEAT) project is to produce continuous records that track the effects of climate change in the equatorial Pacific with enough detail to resolve orbitally forced climate cycles. A significant part of climate change is recorded by variability in the chemical composition of sediments, but this information typically is hard to extract at a reasonable cost.

$\mathrm{X}$-ray fluorescence (XRF) scanning is potentially an economical way to extract the chemical data-it is an X-ray optical technique that can measure most major elements and some minor ones in 20-30 s per measurement. This method can be used to gather chemical data at vertical spacing similar to that at which physical properties data are gathered (e.g., Westerhold and Röhl, 2009). These chemical measurements can augment physical properties measurements to study cyclostratigraphy, and if calibrated, XRF scan data can be used to understand the long-term evolution of biogeochemical cycles.

In this data report, we present the results of XRF scanning on the spliced sedimentary section of PEAT Site U1338 and describe a basic technique to normalize and calibrate the data for further geochemical study. Both the raw and normalized data along the splice are presented in tables. Data at this sampling resolution for the first time allows the study of geochemical cycles for long periods in the Miocene and of how biogeochemical changes are 
associated with long-term changes in global climate.

Site U1338 (Fig. F1; $2^{\circ} 30.469^{\prime} \mathrm{N}, 117^{\circ} 58.178^{\prime} \mathrm{W} ; 4200 \mathrm{~m}$ water depth) is on 18 Ma ocean crust buried by $\sim 400$ $\mathrm{m}$ of pelagic sediment (see the "Site U1338" chapter [Expedition 320/321 Scientists, 2010b]). The sediment drapes over topography so that the $\sim 200 \mathrm{~m}$ abyssal hill relief on basement is still visible despite the $400 \mathrm{~m}$ of sediment cover (Tominaga et al., 2011).

Site U1338 has the characteristic variations in sedimentary calcium carbonate content that result in the common seismic stratigraphy that is found throughout the equatorial Pacific region east of Hawaii (Mayer et al., 1985, 1986; see the "Site U1338" chapter [Expedition 320/321 Scientists, 2010b]; Tominaga et al., 2011). It has been a long-standing scientific problem to understand what forcing mechanisms and associated variations in global geochemical cycles caused the carbonate cycles that in turn caused the common seismic horizons across the equatorial Pacific. XRF scanning potentially can determine calcite contents with sufficient detail to better understand both the links between physical properties and sediment carbonate contents and why sedimentary carbonate varied throughout the eastern equatorial Pacific.

XRF studies of biogeochemically active elements Ca, $\mathrm{Si}$, and $\mathrm{Ba}$ also can be used to understand changes in productivity and can be compared to changes in preservation to better understand changes in the carbon cycle. XRF scanning also can measure aluminosilicate elements ( $\mathrm{Al}, \mathrm{K}$, and $\mathrm{Ti}$ ) to understand dust deposition in the equatorial Pacific, whereas measurements of the redox-sensitive elements $\mathrm{Fe}$ and Mn can be used to study changes in the sedimentary redox environment and hydrothermal activity. Dymond (1981) shows how chemical data can be used to discern sediment processes in the eastern equatorial Pacific.

\section{X-ray fluorescence analytical technique}

$\mathrm{X}$-ray fluorescence is an analytical technique that uses the characteristic fluorescence of elements exposed to high-energy X-ray illumination as a means to estimate a sample's chemical composition. Highenergy X-ray photons eject inner-shell electrons from atoms being illuminated by the X-rays (Jansen et al., 1998). Outer shell electrons in higher energy levels then occupy these lower energy levels, releasing the excess energy as characteristic XRF for each element. The intensity of the fluorescence from a sample can be used to determine the abundance of different elements.

$\mathrm{XRF}$ is a volume and not a mass measurement, however. A conventional chemical analysis measures the amount of an element in a standard mass of total material; a sample with $8 \mathrm{wt} \%$ Fe has, for example, $8 \mathrm{~g}$ Fe per $100 \mathrm{~g}$ sample. For XRF, in contrast, the Xray source illuminates a certain volume of sediment, and the amount of X-rays returned in part depends on the mass of sediment in that volume. Low atomic weight elements emit lower energy X-rays than high atomic weight elements, and these low-energy Xrays are more easily absorbed by other elements as they pass out of the sample. For this reason, light elements have a smaller characteristic emission volume than heavy elements (Tjallingii et al., 2007), causing problems if the sample is not homogeneous.

For unconsolidated sediments, part of the illuminated volume is occupied by pore space, so that the volume XRF return is less than that from a pure solid. Because scanning XRF is a volume measurement, there is a correlation between XRF-scan raw Xray peak areas and wet bulk density (Fig. F2). Low wet bulk density marks samples with high porosity and low solid mass per sample, in contrast to samples with high bulk density. The volume effect most strongly affects the most abundant elements in the samples-in the case of carbonate-rich equatorial Pacific sediments, the correlation is best found with Ca.

In order to remove the volume effect, the data must be normalized before calibration. The normalization method used in this paper (normalized medianscaled sums) is described in "Data reduction methods for later calibration: normalized medianscaled method" later in this data report.

\section{Data acquisition methods}

Data in this data report were acquired at the IODP Gulf Coast Repository in College Station, Texas (USA) (odases.tamu.edu/research-facilities/xrfrequest/), using a third generation Avaatech XRF scanner with a Canberra X-PIPS SDD, model SXD 15C-150-500 $150 \mathrm{eV}$ resolution X-ray detector. The $\mathrm{XRF}$ scanner is configured to analyze split sediment core halves for elements between $\mathrm{Al}$ and $\mathrm{U}$ in the periodic table. The X-ray tube and detector apparatus is mounted on a moving track so that multiple spots at different depths can be analyzed on a split core during the scanning run and multiple scans with different settings can be automatically programmed (Richter et al., 2006). Many parameters are controlled by the operator. For example, there are controls for X- 
ray tube current, voltage, measurement time (live time), X-ray filters used, and area of X-ray illumination. The downcore position step is precise to $0.1 \mathrm{~mm}$.

For Site U1338 XRF scans, sample spacing along each core section was set at $2.5 \mathrm{~cm}$ intervals and separate scans at two voltages were used. One scan was performed at $10 \mathrm{kV}$ for the elements $\mathrm{Al}, \mathrm{Si}, \mathrm{S}, \mathrm{Cl}, \mathrm{K}, \mathrm{Ca}$, $\mathrm{Ti}, \mathrm{Mn}$, and $\mathrm{Fe}$, and a repeat scan was performed at $50 \mathrm{kV}$ for Ba. The voltage used for elements measured is determined by the energy needed to excite the appropriate characteristic X-rays. The X-ray illumination area was set at $1.0 \mathrm{~cm}$ in the downcore direction and $1.2 \mathrm{~cm}$ in the cross-core direction, and the scan was run down the center of the split core half $(6.8 \mathrm{~cm}$ total diameter). Both scans were done with an X-ray tube current of $2 \mathrm{~mA}$. Settings used for Site U1338 $10 \mathrm{kV}$ XRF scans are $2 \mathrm{~mA}$ tube current, no filter, and a detector live time of $20 \mathrm{~s}$; for the 50 $\mathrm{kV}$ scan the settings are $2 \mathrm{~mA}$ current, $\mathrm{Cu}$ filter, and a detector live time of $10 \mathrm{~s}$.

After consultations with colleagues in Bremen, Germany, we now use lower power to preserve tube life and reduce possibility of peak overlap problems. The raw X-ray peak areas are proportional to the power applied. Figure F3A is a comparison of data from XRF scans done at the Gulf Coast Repository on Section 321-U1337A-12H-2 using two different X-ray tube currents at $10 \mathrm{kV}$. For all elements the peak area measured is proportional to the tube current multiplied by the count time. The slope for each elemental data set is near the slope of 0.375 expected from the power-time ratios between the two runs. Figure F3B is a similar comparison between two different Avaatech scanners with different detectors: the Bremen MARUM XRF3 scanner (then equipped with a Canberra SXP 5C-200-1500 V2 $200 \mathrm{eV}$ resolution detector) versus the Gulf Coast Repository scanner (Canberra SXD 15C-150-500 $150 \mathrm{eV}$ resolution detector) on the Eocene/Oligocene boundary section of Hole U1333C (Sections 320-U1333C-14H-4 and 14H-5). The raw data in this comparison are also linearly proportional to power, although different sensitivities of the SXP versus SXD X-ray detectors add an additional linear factor to the count differences. In each example, there is more variability within the light element $(\mathrm{Al})$ measurement where counts are low and air absorption of the low-energy X-rays is more significant. Nevertheless, the different scanners detect a similar chemical signal.

Prior to scanning, each core section was removed from refrigeration at least $2 \mathrm{~h}$ before scanning and was covered $\sim 15 \mathrm{~min}$ before the scanning with $4 \mu \mathrm{m}$ thick Ultralene plastic film (SPEX Centriprep, Inc.). Ultralene film protects the detector face from becom- ing sediment covered and contaminated during the scan. It is important to wait until the core sections warm to room temperature before putting the film on them. Plastic film placed over cool core sections can lead to water condensation on the film and severely reduce light element XRF peak areas by absorbing the emitted low-energy X-rays. We observed in one test a $25 \%-50 \%$ reduction in Ca peak area comparing a cold-run core section to the same section after it was allowed to warm and the Ultralene was replaced. The difference in measured peak area between the warm and cold core was not constant in this particular test but increased downcore on the cold core as the condensation continued to form. Also see Tjallingii et al. (2007) for a discussion of water on light element XRF intensities.

Only core sections along the continuous spliced section of Site U1338 were analyzed, not every core section recovered at the site. We XRF-scanned every archive core half in the Site U1338 splice table (see Table T24 in the "Site U1338" chapter [Expedition $320 / 321$ Scientists, 2010b]). If the splice transferred from one hole to the next in the middle of a section, we ran both entire sections. Therefore, most jump points in the splice have significant overlap. In a few cases where the splice was being revised (J. Dickens, pers. comm., 2011) we also scanned additional sections to help determine the best splice revision. All data gathered, including the overlaps, are included in Table T1. Table T2 has only the data following the published Site U1338 splice (see Table T24 in the "Site U1338" chapter [Expedition 320/321 Scientists, 2010b]), with minor revisions where the meters composite depth (mcd) depths did not match at the tabulated splice point and a revision between 40 and 45 mcd (core composite depth below seafloor [CCSF], method A [overlapping]; see the "Methods" chapter [Expedition 320/321 Scientists, 2010a]) where a mismatch was found by Dickens. Table T2 contains both the raw and normalized median-scaled (NMS) reduced data, described below.

\section{Data reduction methods for later calibration: normalized median-scaled method}

Data reduction was achieved through a simple twostep method: (1) data were scaled by the median shipboard-measured bulk sediment elemental composition to scale the elemental peak areas into typical ranges of sediment composition, and (2) scaled components were then summed and normalized to $100 \%$ to eliminate variability caused by differences 
in porosity or cracks. This method of data reduction has a few similarities and several differences with that of Weltje and Tjallingii (2008). Weltje and Tjallingii (2008) normalize the peak areas first and then $\log$ transform the peak areas to reduce the range between major and minor XRF-emitters, like our median-scaling step. Finally, they solve a matrix of XRF element/element ratios for composition. The Weltje and Tjallingii (2008) approach has the advantage of being more global and developed from first principles, but it suffers from complexity and is not easily adapted. The advantage of the NMS technique is that it can be quickly implemented, and the calibration step can be used to determine if a more detailed approach is needed.

\section{Sample scaling}

Sample scaling is needed to better match the range of XRF peak area measurements to the range of chemical composition along the scan. Without scaling, normalized peak areas can be dominated by effects of one element.

For an elemental scaling $S_{e}$,

$$
\mathrm{S}_{\mathrm{e}}=\mathrm{Med}_{\mathrm{e}} \times\left(\text { PeakArea }_{\mathrm{e}} / \text { PeakArea }_{\mathrm{e}, \mathrm{med}}\right),
$$

where Med $\%_{\mathrm{e}}$ is the median weight percent of a sedimentary component (e.g., for Fe, we used the oxide $\mathrm{Fe}_{2} \mathrm{O}_{3}$, and for $\mathrm{Ca}, \mathrm{CaCO}_{3}$ ). PeakArea $\mathrm{e}_{\mathrm{e}}$ is the measured elemental peak area in a sample, and PeakArea ${ }_{e, \text { med }}$ is the median peak area over the data set. There may be errors in absolute scaling because the chemical analyses are far fewer than the XRF sampling. The raw $\mathrm{CaCO}_{3}$ data, for example, scales from $0 \%$ to $\sim 120 \%$. However, the normalizing step reduces the total range to between $0 \%$ and $100 \%$, and the calibration step correlating the scaled data to groundtruth chemical analyses produces a linear correlation that does a final adjustment to the percentage data.

Scaling the raw peak areas was done because the production of characteristic X-rays of different elements does not scale linearly with elemental ratios in the sample. Scaling to the total summed peak area was rejected because scaling to raw peak area strongly overweights $\mathrm{Ca}$ in the carbonate-rich sediment column of Site U1338 and is a significant cause of nonlinearities in later calibration. Scaling to total peak area is effectively equivalent to scaling to $\mathrm{Ca}$ peak area, as is shown by comparing Ca proportions in the two scaling schemes. Median peak area of $\mathrm{Ca}$ is $95 \%$ of summed total median peak area, whereas median $\mathrm{CaCO}_{3}$ is $76 \%$ of the summed shipboard chemical analyses. The raw peak area $\mathrm{Ca} / \mathrm{Si}$ ratio is 38.5 , whereas the ratio of median $\mathrm{CaCO}_{3} / \mathrm{SiO}_{2}$ from ship- board inductively coupled plasma-atomic emission spectroscopy (ICP-AES) analyses is 4.9. Summing to raw peak areas thus creates a burden that must be removed by the calibration step, whereas scaling to median values reduces the problem.

We scaled each element independently to a median of the compositional data from shipboard ICP-AES analyses (see the "Site U1338" chapter [Expedition 320/321 Scientists, 2010b]). Although the shipboard compositional data set is a much smaller sample set than the XRF scan data, it is appropriate for scaling as long as the compositional data set is a reasonable representation of the total range of composition. The scaling step could also be done with a generic average for the sediment type being studied if chemical data were not available. The use of a different "type" compositional analysis to scale the median value will change the ultimate NMS value and will then potentially change the slope of the calibration line to convert from NMS to calibrated percent. It is thus important to use the same scaling values within a common calibration.

\section{Normalizing sample composition to $100 \%$}

Ideally, the sum of all sediment components should be $100 \%$ if all major elements are measured and they are properly converted to the appropriate sedimentary components (e.g., $\mathrm{Ca}$ is represented in the sediment by the sedimentary component $\mathrm{CaCO}_{3}$, not $\mathrm{CaO}$ ). However, The XRF-scaled sum of components is often much lower than 100\% near the top of the section where porosity is high and dry sample mass in the scan area is low. We used the following components for our data set: $\mathrm{Al}_{2} \mathrm{O}_{3}, \mathrm{SiO}_{2}, \mathrm{~K}_{2} \mathrm{O}, \mathrm{CaCO}_{3}$, $\mathrm{TiO}_{2}, \mathrm{MnO}, \mathrm{Fe}_{2} \mathrm{O}_{3}$, and $\mathrm{BaSO}_{4}$. From the shipboard chemical analyses, these components sum to a median of 94.7 wt $\%$ and adequately represent all sediment components. In contrast, the high-porosity upper $50 \mathrm{~m}$ of Site U1338 has a median of $67 \mathrm{wt} \%$ for the raw sum of components and a range from $<20 \%$ to $\sim 100 \%$. Clearly, the raw sum has significant noise and is affected by the sediment water content.

The normalization procedure is basic-multiply each component by $100 /$ (raw sum) to bring the total sum of components to $100 \%$, or

$$
\mathrm{NMS}_{\mathrm{c}}=\mathrm{C} \times 100 /(\text { raw sum }),
$$

where $\mathrm{NMS}_{\mathrm{c}}$ is the normalized median-scaled value for the component and $\mathrm{C}$ is the median-scaled value of the component.

Normalization does a good job of removing the volume versus mass XRF effect. Near the surface of the sediment column, the major cause of low sums of 
median-scaled data is the porosity effect. Deeper in the sediment section, however, the raw sum (and raw peak areas) are often variable because the sediment is stiffer and the core surface is cracked or sufficiently uneven that the X-ray detector assembly lands imperfectly (Fig. F4). Normalization minimizes this high-frequency noise. Figure $\mathbf{F} 4$ shows the raw median-scaled $\mathrm{CaCO}_{3}$ and the NMS $\mathrm{CaCO}_{3}$ in a deeper section of the Site U1338 splice (Table T2). Scaling and normalization reduced what appears to be noise in the measurement and made the total range more similar to the variability in the low-resolution $\mathrm{CaCO}_{3}$ record (Lyle and Backman, submitted).

The scaling and normalization process in this data report provides a way to develop a quantitative estimate of sediment concentration based on XRF scans. However, one should always be aware that XRF estimates can have significant errors if the model of sediment composition used is seriously awry (e.g., that the "type" sediment composition used is significantly different from actual sediment composition). Another source of significant error can occur if the model sediment components don't match those of the sediment or if a major element found in the sediments is not included in the model. However, despite these issues, NMS data are significantly better to study the changes in sediment composition than raw XRF peak area. Raw peak area data can have even larger relative errors resulting from significant differences in porosity between sediment layers or from technical problems landing the detector on a flat sediment surface.

\section{Example calibration of data: $\mathrm{BaSO}_{4}$}

A final step-calibration with chemical analyses of the sediments-is required in order to properly estimate chemical composition with XRF. Figure F5 illustrates the basic process with shipboard $\mathrm{Ba}$ data,

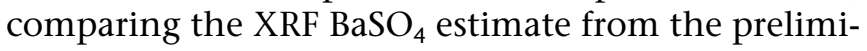
nary linear calibration with the shipboard measurements. The shipboard data set is not ideal for this calibration because the shipboard and XRF data were often measured on different holes but matched by the common meters composite depth used to build the splice. Nonlinear distortions of adjacent sediment columns, either by coring or local sedimentation variability, add noise to the calibration by matching samples at different sediment horizons (Hagelberg et al., 1995). Compositional differences may actually exist between the shipboard ICP-AES and XRF NMS data that we used for the initial test calibrations. Also, we did not have a sufficient number of samples to reserve some for a test data set to determine errors. Nevertheless, the correlation between the shipboard ICP-AES data and XRF Ba data is reasonably good and will be improved by measuring more samples along the splice.

A better example calibration exists for $\mathrm{CaCO}_{3}$ data (Lyle and Backman, submitted). Lyle and Backman use an extensive discrete $\mathrm{CaCO}_{3}$ data set to calibrate an $\mathrm{XRF} \mathrm{CaCO}_{3}$ estimate. Only half of the data are used for the calibration. A reserved half of the data set is used to assess the quality of the calibration. Reserving data allowed Lyle and Backman to show that the $\mathrm{CaCO}_{3}$ estimate agreed with the measured $\mathrm{CaCO}_{3}$ by $\pm 5 \mathrm{wt} \%$ (1 standard deviation).

\section{Results and discussion}

One of the important uses of XRF scanning is to be able to produce high-resolution data sets of chemical composition for long time spans (e.g., the 18 m.y. sediment record at Site U1338). Figure F6 shows NMS time series of $\mathrm{CaCO}_{3}$ and $\mathrm{SiO}_{2}$. These two components average $\sim 90 \%$ of the total sediment composition. Multiple intervals of low carbonate at Site U1338 are marked by tan bars on Figure F6. Each of these intervals have high $\mathrm{SiO}_{2}$, caused by either the dissolution loss of carbonate from the sediment column or by the very fast deposition of an $\mathrm{SiO}_{2}$-rich sediment component, like the late Miocene-Pliocene diatom mat deposits found in the eastern equatorial Pacific (Kemp and Baldauf, 1993; Expedition 320/ 321 Scientists, 2010b). One of the primary tasks of postexpedition studies is to understand how primary productivity and dissolution during early diagenesis have shaped the composition of the sediment column. Based on an average sedimentation rate of 25$30 \mathrm{~m} / \mathrm{m}$.y. below 60 revised meters composite depth (rmcd) in Site U1338 (see the "Site U1338" chapter [Expedition 320/321 Scientists, 2010b]) large-scale low weight percent $\mathrm{CaCO}_{3}$ transients are spaced a million or more years apart. Smaller scale $\mathrm{CaCO}_{3}$ variability is also observed at all the typical orbital forcing periods-400 to $19 \mathrm{k} . \mathrm{y}$.

One way to study the aluminosilicate signal is with an aluminosilicate element like Ti. Because of low levels of aluminosilicates in the biogenic-rich equatorial Pacific sediments, it is more appropriate to use $\mathrm{Ti}$ than $\mathrm{Al}$, because sufficient $\mathrm{Al}$ can be bound to bio$\mathrm{SiO}_{2}$ to cause an appreciable Al signal, especially at intervals in the sediment column where bio- $\mathrm{SiO}_{2}$ was initially deposited at the seafloor but then partly dissolved during early diagenesis (Dymond et al., 1997). Figure F7 is a plot of $\mathrm{TiO}_{2}$ and $\mathrm{SiO}_{2}$ NMS concentra- 
tions along the Site U1338 splice. The blue intervals mark intervals where $\mathrm{SiO}_{2}$ is very high but $\mathrm{TiO}_{2}$ is essentially zero. These sediment intervals are extremely rich in bio- $\mathrm{SiO}_{2}$. In the upper $60 \mathrm{~m}$ of the sediment column (tan interval), we observe higher $\mathrm{TiO}_{2}$ associated with moderate $\mathrm{SiO}_{2}$, indicating relatively more clays. This interval marks the last 5 m.y. of the record as the site moved north of $1.3^{\circ} \mathrm{N}$ to its present position at $2.6^{\circ} \mathrm{N}$. The increase in clay component may represent increased dissolution of bio$\mathrm{SiO}_{2}$ and $\mathrm{CaCO}_{3}$ as sedimentation slowed down when Site U1338 moved away from the equatorial high-productivity zone or increased dust deposition as Site U1338 moves toward the Intertropical Convergence Zone. The interval of elevated Ti coincides with the upper section of core with lower sedimentation rates $(12.7 \mathrm{~m} / \mathrm{m}$.y. versus $28.7 \mathrm{~m} / \mathrm{m}$.y. below; see Fig. F14 in the "Site U1338" chapter [Expedition 320/321 Scientists, 2010b]). Mass accumulation rates of $\mathrm{TiO}_{2}$, based on preliminary linear sedimentation rates, do not change with the increase in $\mathrm{TiO}_{2} \%$. The lack in change of flux makes the biogenic sediment dissolution hypothesis the most probable cause for $\mathrm{TiO}_{2}$ enrichment in the upper section, not higher dust deposition. Supporting this interpretation, the modern position of Site U1338 is well south of the dust maximum associated with the Intertropical Convergence Zone, $5^{\circ}-6^{\circ} \mathrm{N}$ since 5 Ma (Hovan, 1995).

\section{Conclusions}

We present scanning XRF data along the splice of Site U1338 (21,000 total sample measurements, with 17,000 along the splice) and show their use to explore the history of the equatorial Pacific productivity zone. We found that we could scan the Site U1338 splice in a reasonably short amount of time, averaging a little over $1 \mathrm{~h}$ apiece to scan $\sim 250$ sections along the Site U1338 splice for Al, Si, K, Ca, Ti, $\mathrm{Mn}, \mathrm{Fe}$, and $\mathrm{Ba}$. Raw data are a volume measurement, however, and must be scaled, normalized, and eventually calibrated to make an estimate of sediment composition. The NMS data reduction process we describe helps to make correlations between raw peak areas and measured chemical compositions more linear so that calibration is easier. To achieve good results, care must be taken to choose a sediment compositional model (median composition and type of sediment components) that is similar to the sediments under analysis. Calibration is the final step to convert XRF scan data to a compositional estimate. Ideally, sufficient numbers of samples are measured by other analytical methods that some of the data are left out of the calibration and can be used as check data.

\section{Acknowledgments}

We thank IODP Expedition 320/321 party members, IODP, and the IODP Gulf Coast Repository (GCR) for providing samples and data for this report and for all the effort they put in to properly collect and archive the Site U1338 sediment cores. We also acknowledge the Ocean Drilling and Sustainable Earth Sciences (ODASES) program at Texas A\&M University for acquiring the Avaatech XRF scanner for the GCR. Scanning and analysis were paid for by a USAC postcruise grant and by NSF grant OCE-0962184 to ML and AOL. TW was funded by the Deutsche Forschungsgemeinschaft (DFG)-Leibniz Center for Surface Process and Climate Studies at the University of Potsdam.

\section{References}

Dymond, J., 1981. Geochemistry of Nazca plate surface sediments: an evaluation of hydrothermal, biogenic, detrital, and hydrogenous sources. In Kulm, L.D., Dymond, J., Dasch, E.J., Hussong, D.M., and Roderick, R. (Eds.), Nazca Plate: Crustal Formation and Andean Convergence. Mem.-Geol. Soc. Am., 154:133-173.

Dymond, J., Collier, R., McManus, J., Honjo, S., and Manganini, S., 1997. Can the aluminum and titanium contents of ocean sediments be used to determine the paleoproductivity of the oceans? Paleoceanography, 12(4):586-593. doi:10.1029/97PA01135

Expedition 320/321 Scientists, 2010a. Methods. In Pälike, H., Lyle, M., Nishi, H., Raffi, I., Gamage, K., Klaus, A., and the Expedition 320/321 Scientists, Proc. IODP, 320/ 321: Tokyo (Integrated Ocean Drilling Program Management International, Inc.). doi:10.2204/

iodp.proc.320321.102.2010

Expedition 320/321 Scientists, 2010b. Site U1338. In Pälike, H., Lyle, M., Nishi, H., Raffi, I., Gamage, K., Klaus, A., and the Expedition 320/321 Scientists, Proc. IODP, 320/321: Tokyo (Integrated Ocean Drilling Program Management International, Inc.). doi:10.2204/ iodp.proc.320321.110.2010

Hagelberg, T.K., Pisias, N.G., Mayer, L.A., Shackleton, N.J., and Mix, A.C., 1995. Spatial and temporal variability of late Neogene equatorial Pacific carbonate: Leg 138. In Pisias, N.G., Mayer, L.A., Janecek, T.R., Palmer-Julson, A., and van Andel, T.H. (Eds.), Proc. ODP, Sci Results, 138: College Station, TX (Ocean Drilling Program), 321-336. doi:10.2973/odp.proc.sr.138.116.1995

Hovan, S.A., 1995. Late Cenozoic atmospheric circulation intensity and climatic history recorded by eolian deposition in the eastern equatorial Pacific Ocean, Leg 138. 
In Pisias, N.G., Mayer, L.A., Janecek, T.R., Palmer-Julson, A., and van Andel, T.H. (Eds.), Proc. ODP, Sci. Results, 138: College Station, TX (Ocean Drilling Program), 615625. doi:10.2973/odp.proc.sr.138.132.1995

Jansen, J.H.F., Van der Gaast, S.J., Koster, B., and Vaars, A.J., 1998. CORTEX, a shipboard XRF-scanner for element analyses in split sediment cores. Mar. Geol., 151(14):143-153. doi:10.1016/S0025-3227(98)00074-7

Kemp, A.E.S., and Baldauf, J.G., 1993. Vast Neogene laminated diatom mat deposits from the eastern equatorial Pacific Ocean. Nature (London, U. K.), 362(6416):141144. doi:10.1038/362141a0

Lyle, M., and Backman, J., submitted. Data report: calibration of XRF-estimated $\mathrm{CaCO}_{3}$ along the Site U1338 splice. In Pälike, H., Lyle, M., Nishi, H., Raffi, I., Gamage, K., Klaus, A., and the Expedition 320/321 Scientists, Proc. IODP, 320/321: Tokyo (Integrated Ocean Drilling Program Management International, Inc.).

Mayer, L.A., Shipley, T.H., Theyer, F., Wilkens, R.H., and Winterer, E.L., 1985. Seismic modeling and paleoceanography at Deep Sea Drilling Project Site 574. In Mayer, L., Theyer, F., Thomas, E., et al., Init. Repts. DSDP, 85: Washington, DC (U.S. Govt. Printing Office), 947-970. doi:10.2973/dsdp.proc.85.132.1985

Mayer, L.A., Shipley, T.H., and Winterer, E.L., 1986. Equatorial Pacific seismic reflectors as indicators of global oceanographic events. Science, 233(4765):761-764. doi:10.1126/science.233.4765.761

Richter, T.O., van der Gaast, S., Koster, B., Vaars, A., Gieles, R., de Stigter, H.C., De Haas, H., and van Weering,
T.C.E., 2006. The Avaatech XRF Core Scanner: technical description and applications to NE Atlantic sediments. In Rothwell, R.G. (Ed.), New Techniques in Sediment Core Analysis. Geol. Soc. Spec. Publ., 267(1):39-50. doi:10.1144/GSL.SP.2006.267.01.03

Tjallingii, R., Röhl, U., Kölling, M., and Bickert, T., 2007. Influence of the water content on X-ray fluorescence core-scanning measurements in soft marine sediments. Geochem., Geophys., Geosyst., 8(2):Q02004. doi:10.1029/ 2006GC001393

Tominaga, M., Lyle, M., and Mitchell, N.C., 2011. Seismic interpretation of pelagic sedimentation regimes in the 18-53 Ma eastern equatorial Pacific: basin-scale sedimentation and infilling of abyssal valleys. Geochem., Geophys., Geosyst., 12(3):Q03004. doi:10.1029/ 2010GC003347

Weltje, G.J., and Tjallingii, R., 2008. Calibration of XRF core scanners for quantitative geochemical logging of sediment cores: theory and application. Earth Planet. Sci. Lett., 274(3-4):423-438. doi:10.1016/ j.eps1.2008.07.054

Westerhold, T., and Röhl, U., 2009. High resolution cyclostratigraphy of the early Eocene-new insights into the origin of the Cenozoic cooling trend. Clim. Past, 5(3):309-327. doi:10.5194/cp-5-309-2009

Initial receipt: 2 September 2011

Acceptance: 1 November 2011

Publication: 29 February 2012

MS 320321-203 
Figure F1. (A) Site map and (B) swath bathymetry map of Site U1338, located on 18 Ma crust formed at the East Pacific Rise (from the "Site U1338" chapter [Expedition 320/321 Scientists, 2010b]). Plate tectonic movement of the Pacific plate carried Site U1338 within $0.5^{\circ}$ of the Equator between 13 and 8 Ma.
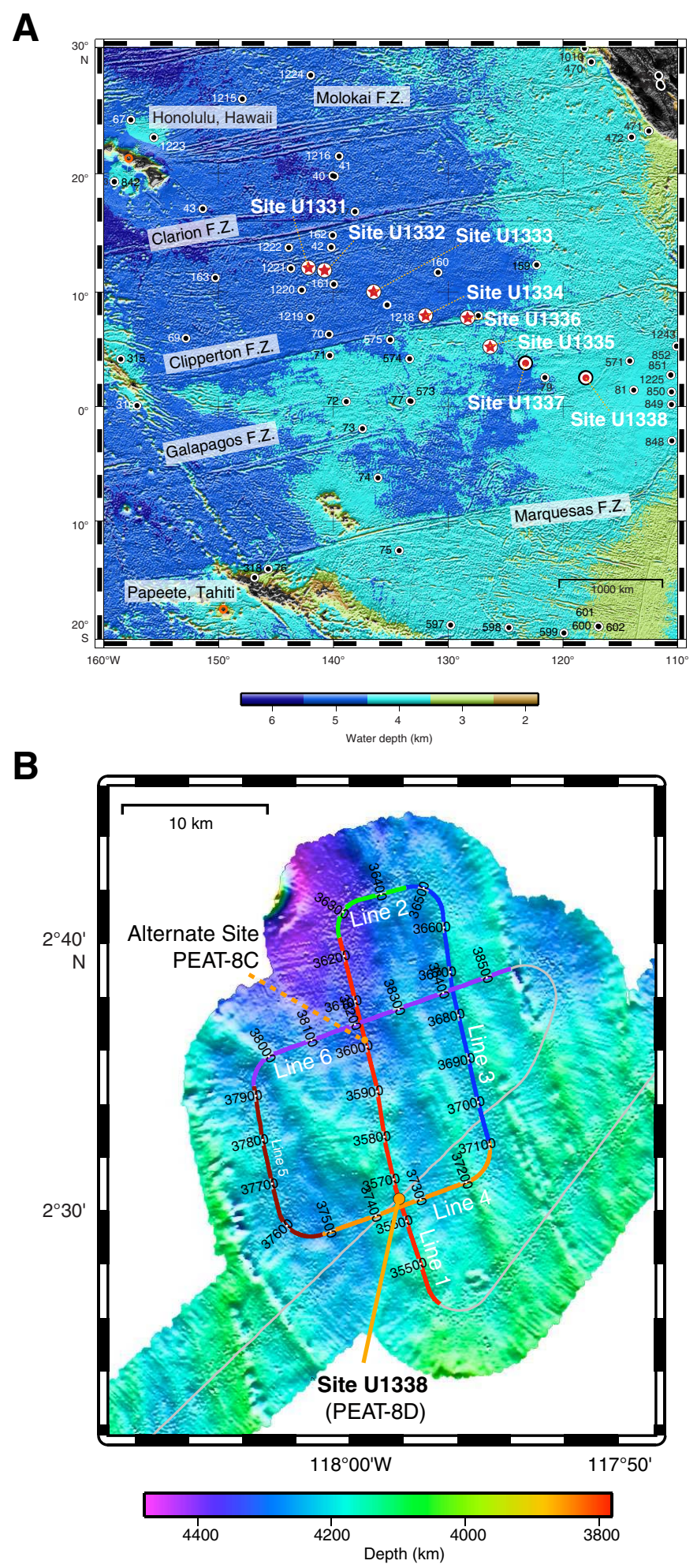
Figure F2. Raw sum of XRF-estimated sedimentary components compared to gamma ray attenuation (GRA) bulk density along the Site U1338 splice, reported in core composite depth below seafloor (CCSF), method B (compressed), showing the correlation between wet bulk density and the sum. The correlation exists because XRF scanning is a volume measurement and fluorescent X-ray returns depend on the total mass in the volume, which is related to the wet bulk density.

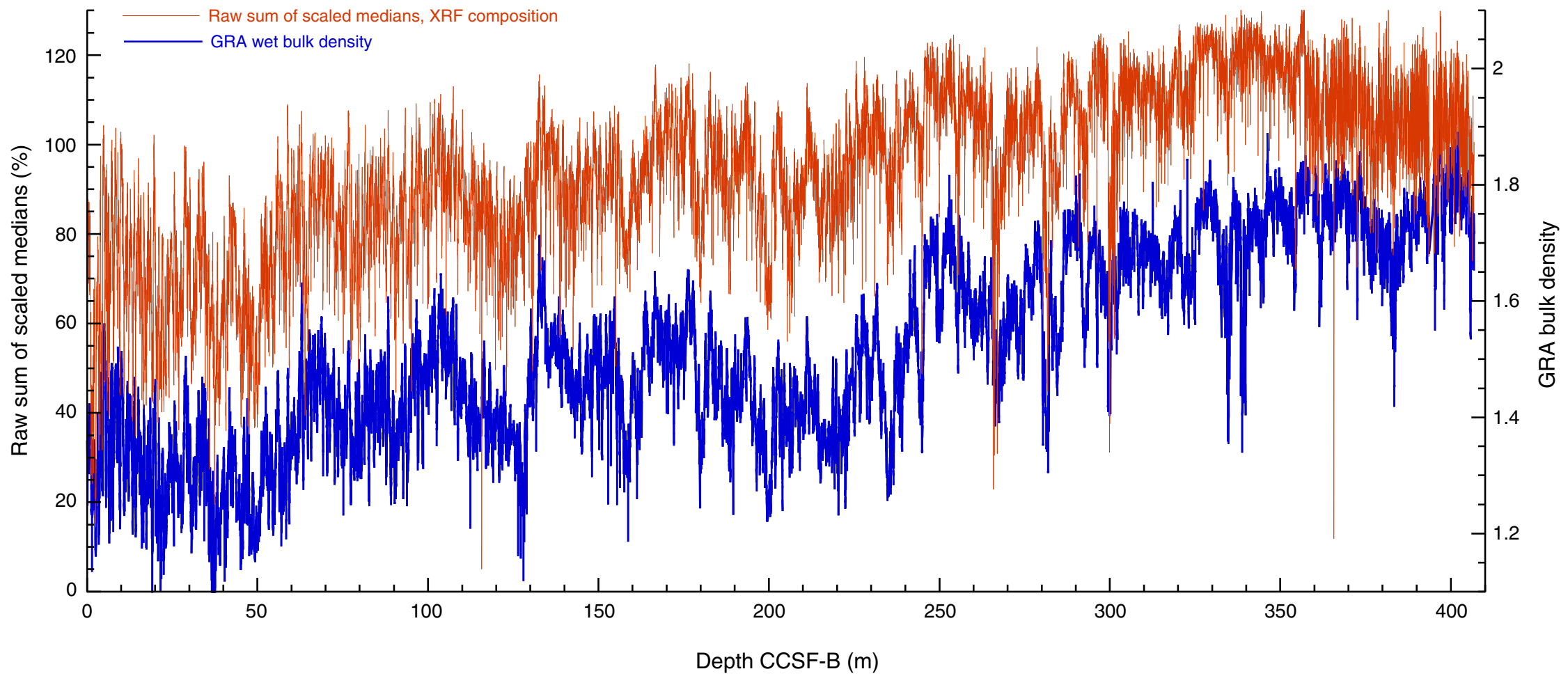


Figure F3. XRF scans run at two different tube currents to show the effect of power on peak areas and the effect of different detectors. A. Al and Fe scans at the Gulf Coast Repository (GCR) for Section 321-U1337A-12H-2 using $0.5 \mathrm{~mA}$ and $30 \mathrm{~s}$ live time (red line) vs. $2 \mathrm{~mA}$ and $20 \mathrm{~s}$ live time (blue line). Top plots in each shows a scatter plot of the individual samples. (Continued on next page.)

A

GCR, 2 power settings
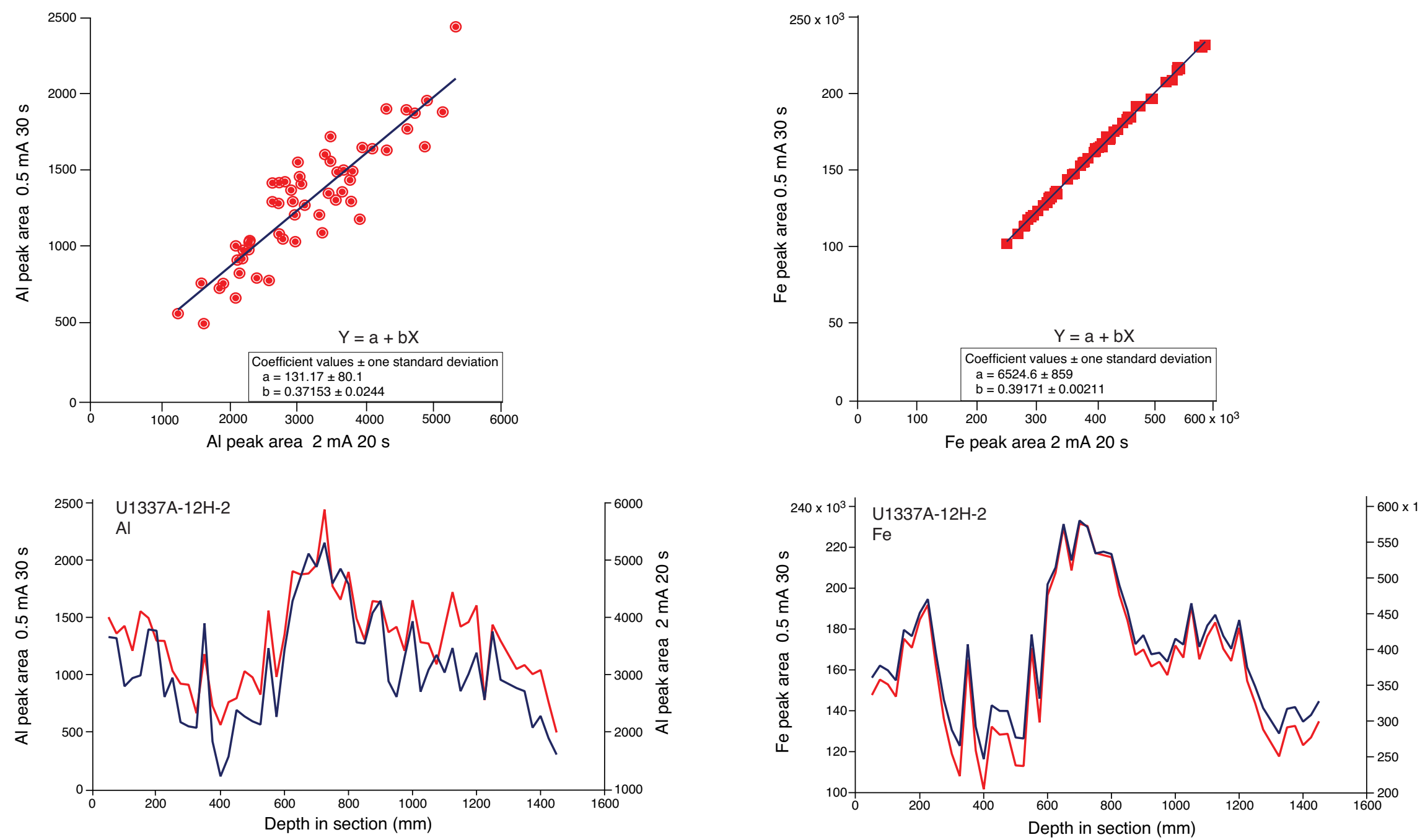
Figure F3 (continued). B. Al and Fe scans comparing the MARUM XRF 3 Avaatech scanner (Bremen; red line) with tube current of 0.12 mA and 20 s live time to the scans from the Gulf Coast Repository (GCR) Avaatech scanner using a tube current of $2 \mathrm{~mA}$ and $20 \mathrm{~s}$ live time (blue line). The two scanners have different generations of detectors with different sensitivity, but these differences did not appreciably affect the shape of the depth profiles. Top plots in each shows a scatter plot of the individual samples.

\section{B}

GCR and MARUM, 2 power settings
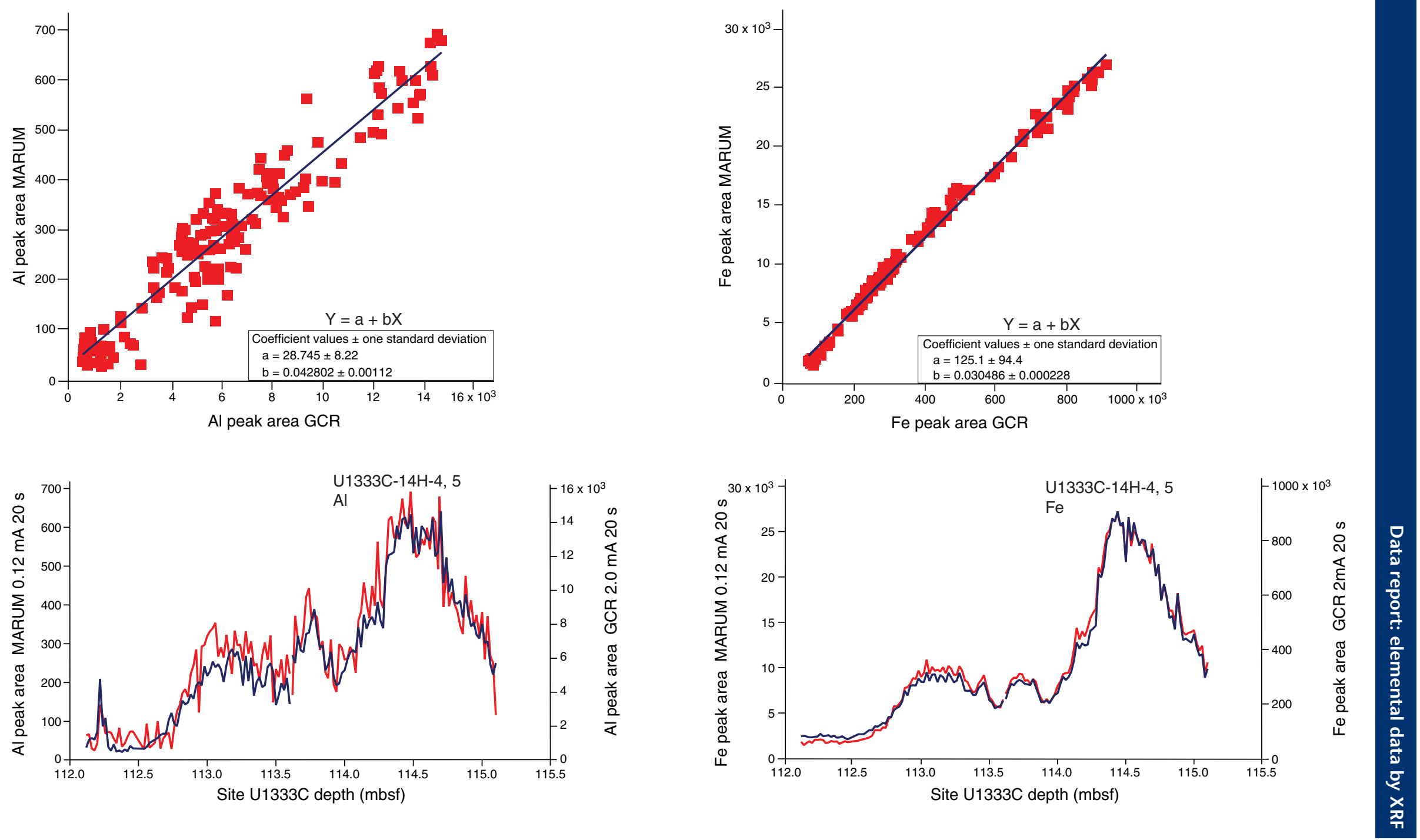
Figure F4. Comparison of raw median-scaled $\mathrm{CaCO}_{3}$ data (green) with normalized (NMS) $\mathrm{CaCO}_{3}$ estimate (blue), and discrete low-resolution $\mathrm{CaCO}_{3}$ (J. Backman, unpubl. data) over the interval 400-420 mcd on the Site U1338 splice, shown in core composite depth below seafloor (CCSF), method A (overlapping). Raw data are significantly more variable because it is more difficult to land the XRF detector perfectly on the cracked and uneven surface of stiffer sediments. Normalizing the sum of components to $100 \%$ significantly removes the amount of sample-to-sample variability.

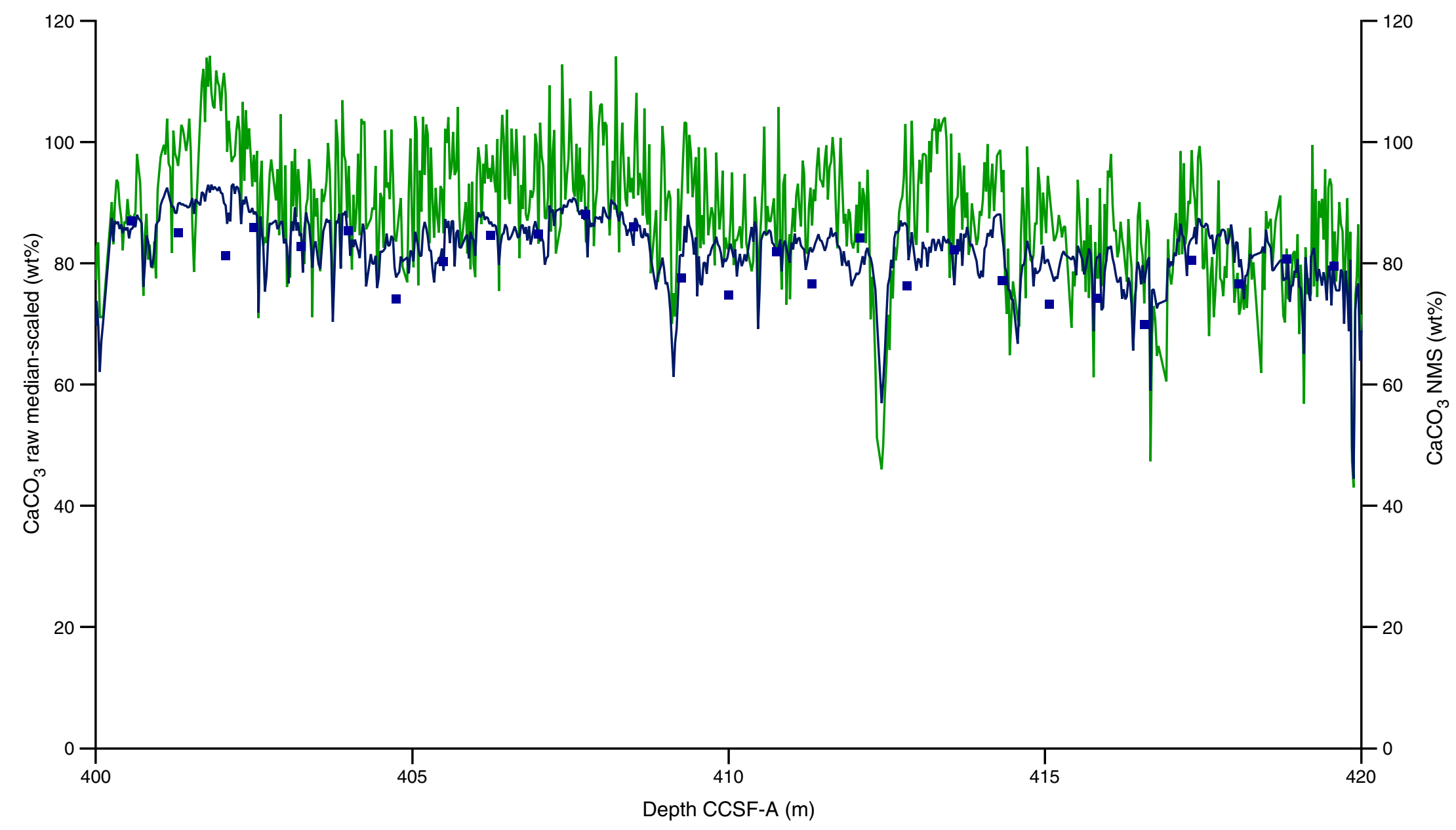


Figure F5. Comparison of the preliminary XRF-estimated $\mathrm{BaSO}_{4}$ (red) to shipboard Ba (blue) measured by inductively coupled plasma-atomic emission spectroscopy (ICP-AES) expressed as $\mathrm{BaSO}_{4}$. Calibration graph is shown on right. Additional samples are needed for the calibration to better sample the range in Ba variability, but the match is encouraging. NMS = normalized.

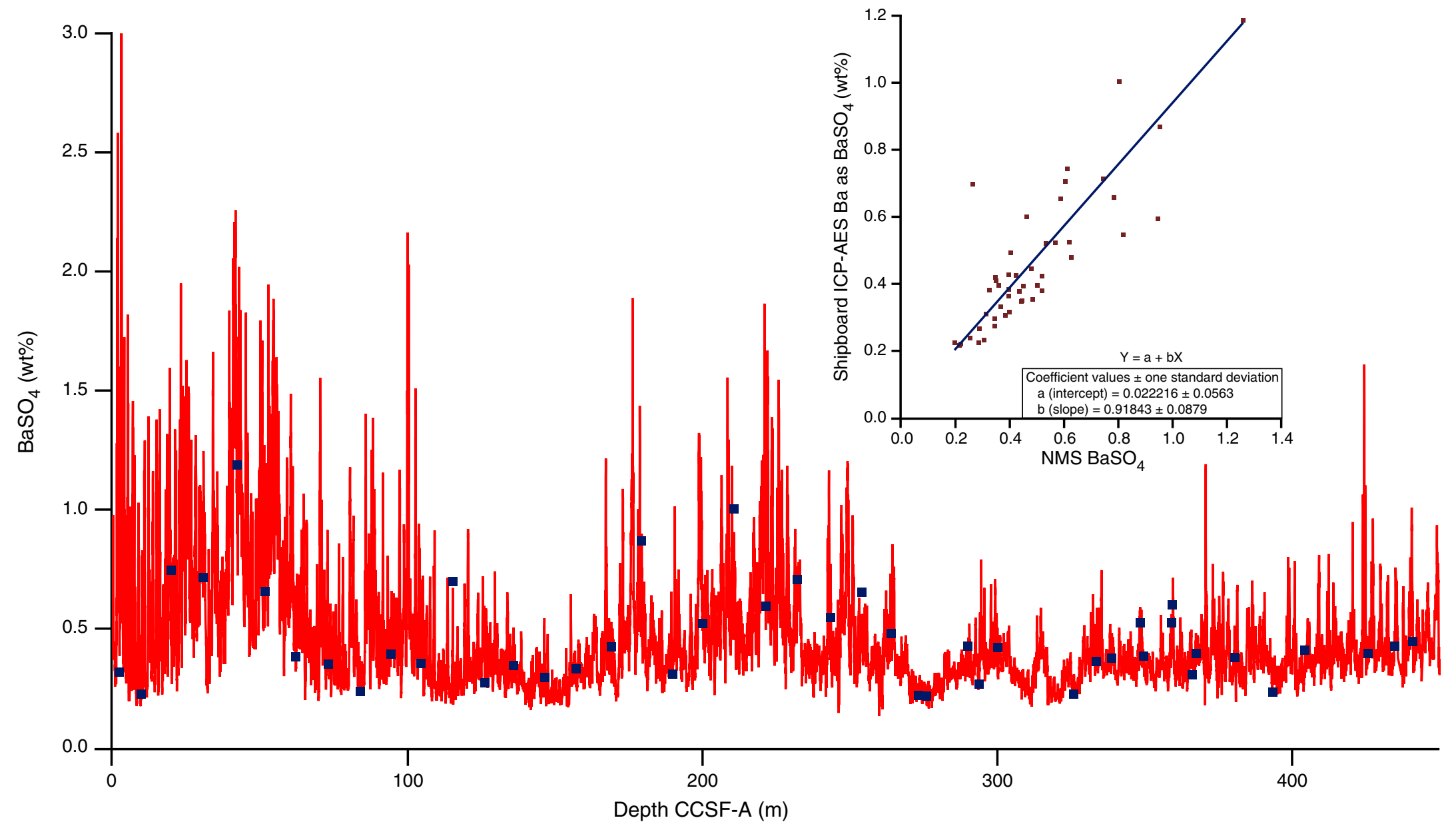


Figure F6. Comparison of uncalibrated normalized (NMS) $\mathrm{CaCO}_{3} \%$ (red) and $\mathrm{SiO}_{2} \%$ (blue) along the Site U1338 splice. Tan bands highlight prominent $\mathrm{CaCO}_{3}$ lows $/ \mathrm{SiO}_{2}$ highs. Much of the $\mathrm{SiO}_{2}$ at Site $\mathrm{U} 1338$ is biogenic, so these represent either high bio-Si production and burial or high CaCO dissolution. Higher resolution periodicity is apparent in the records and will be used for tuning sedimentation rates and to understand how the biogenic components respond to orbital forcing.

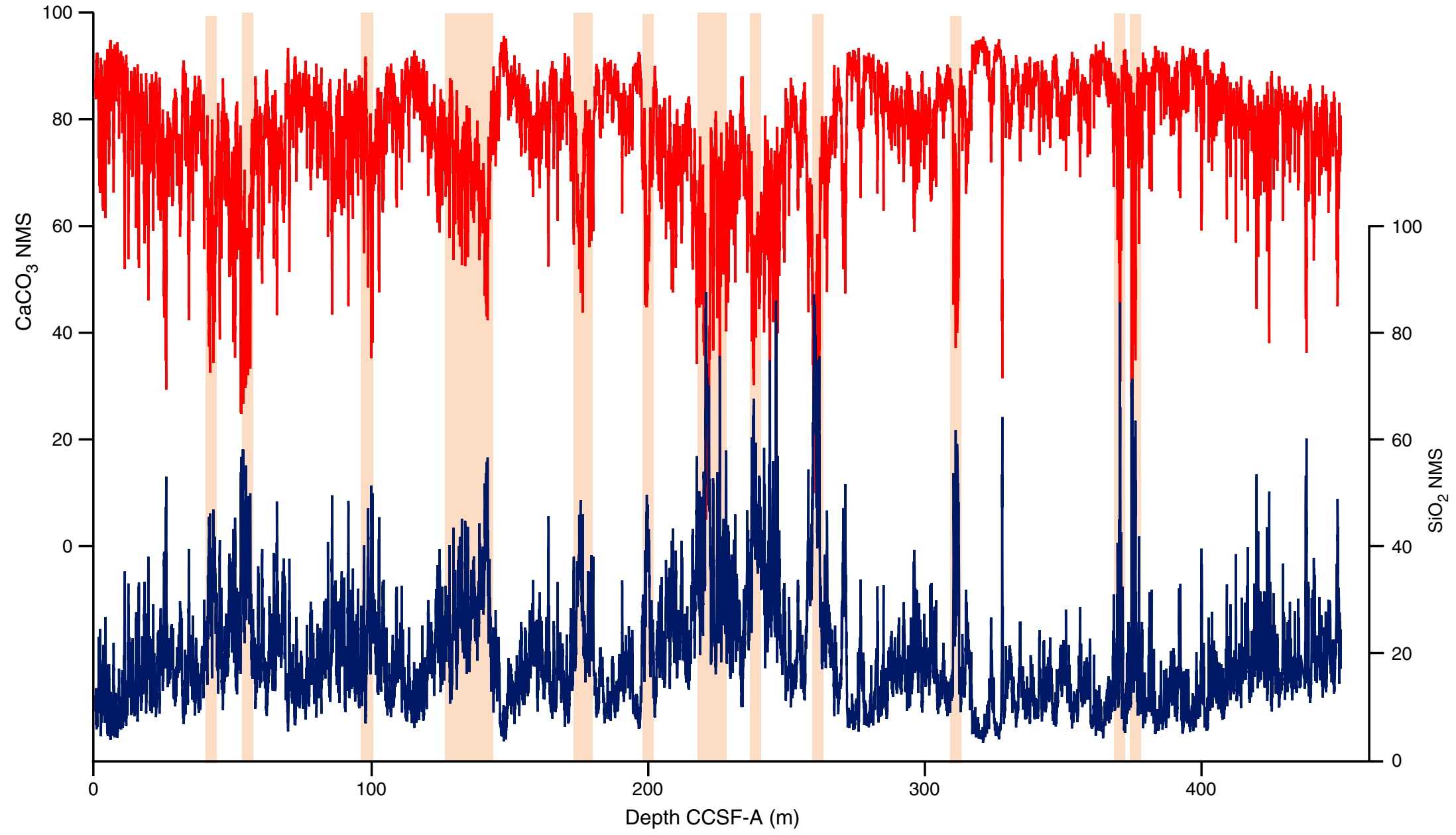


Figure F7. Comparison of uncalibrated normalized (NMS) $\mathrm{TiO}_{2} \%$ (brown) and $\mathrm{SiO}_{2} \%$ (blue) to discern clay (aluminosilicate) vs. biogenic contributions to the $\mathrm{SiO}_{2}$ signal. Blue bands mark high biogenic- $\mathrm{SiO}_{2}$, determined when the $\mathrm{SiO}_{2}$ is at a maximum but aluminosilicate elements like TiO disappear. The brown band at the top of the sediment section is an area with moderate $\mathrm{SiO}_{2}$ but relatively high amounts of $\mathrm{TiO}_{2}$, representing elevated aluminosilicates compared to the rest of the core. $\mathrm{TiO}_{2}$ probably increases because of additional dissolution of bio-SiO ${ }_{2}$ as sedimentation rates slow.

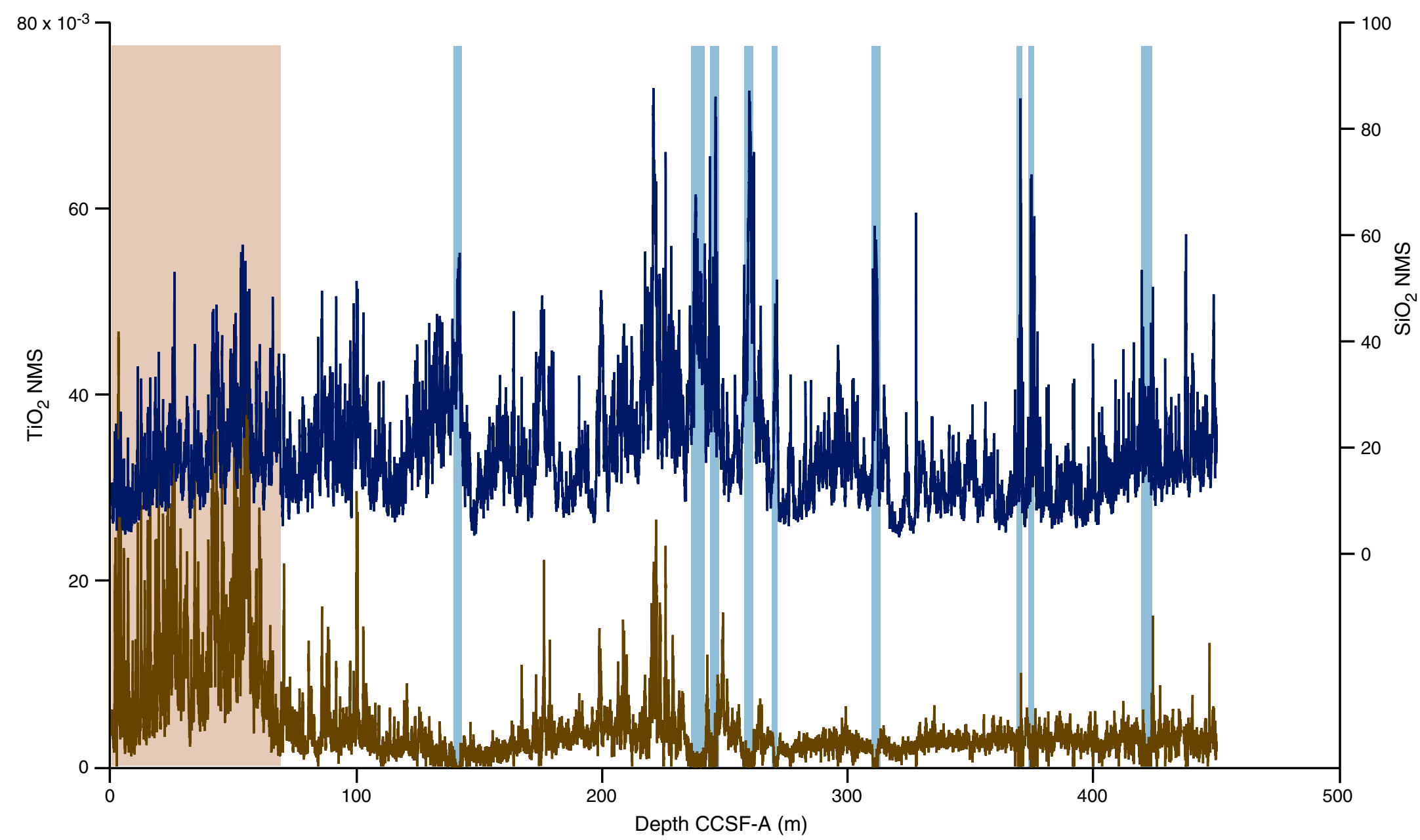


Table T1. Raw XRF scan peak area data for all scans on Site U1338, unspliced.

\begin{tabular}{|c|c|c|c|c|c|c|c|c|c|c|c|c|c|c|}
\hline Core, section & $\begin{array}{l}\text { Depth in } \\
\text { section } \\
(\mathrm{mm})\end{array}$ & $\begin{array}{c}\text { Measurement } \\
\text { date } \\
(2009)\end{array}$ & $\begin{array}{c}\text { Depth } \\
\text { (mbsf/ } \\
\text { CSF-A } \\
{[\mathrm{m}] \text { ) }}\end{array}$ & $\begin{array}{c}\text { Depth } \\
\text { (mcd/ } \\
\text { CCSF-A } \\
[\mathrm{m}])\end{array}$ & $\mathrm{Al}$ area & Si area & $\mathrm{S}$ area & $\mathrm{Cl}$ area & $\mathrm{K}$ area & Ca area & Ti area & $\mathrm{Mn}$ area & Fe area & $\begin{array}{c}\text { Ba area } \\
(50 \mathrm{kV} \\
\text { scan })\end{array}$ \\
\hline \multicolumn{15}{|l|}{ 321-U1338A- } \\
\hline $1 \mathrm{H}-1$ & 25 & $29 \mathrm{Jul}$ & 0.025 & 0.065 & -196 & 31,096 & 13,457 & 293,730 & $-1,343$ & $2,258,381$ & 1,320 & 65,711 & 50,683 & 3,398 \\
\hline $1 \mathrm{H}-1$ & 50 & 29 Jul & 0.050 & 0.090 & -98 & 39,489 & 27,680 & 771,065 & 7,437 & $2,914,316$ & 3,180 & 114,737 & 90,042 & 12,199 \\
\hline $1 \mathrm{H}-1$ & 75 & 29 Jul & 0.075 & 0.115 & 31 & 54,291 & 25,702 & 670,383 & 7,910 & $3,917,938$ & 4,312 & 120,200 & 89,287 & 10,974 \\
\hline $1 \mathrm{H}-1$ & 100 & 29 Jul & 0.100 & 0.140 & -64 & 58,567 & 25,225 & 649,819 & 8,859 & $3,879,549$ & 4,132 & 120,278 & 90,977 & 9,940 \\
\hline $1 \mathrm{H}-1$ & 125 & $29 \mathrm{Jul}$ & 0.125 & 0.165 & 261 & 74,200 & 21,599 & 559,320 & 8,642 & $5,529,714$ & 5,545 & 150,111 & 90,424 & 10,158 \\
\hline $1 \mathrm{H}-1$ & 150 & 29 Jul & 0.150 & 0.190 & 474 & 99,029 & 21,387 & 577,860 & 9,292 & $5,459,765$ & 4,785 & 116,935 & 94,039 & 9,623 \\
\hline $1 \mathrm{H}-1$ & 175 & 29 Jul & 0.175 & 0.215 & 294 & 79,255 & 22,413 & 611,799 & 7,209 & $5,622,123$ & 5,203 & 148,228 & 87,932 & 9,972 \\
\hline $1 \mathrm{H}-1$ & 200 & 29 Jul & 0.200 & 0.240 & 168 & 78,416 & 24,243 & 606,554 & 7,054 & $5,460,881$ & 5,675 & 143,363 & 89,331 & 9,665 \\
\hline $1 \mathrm{H}-1$ & 225 & 29 Jul & 0.225 & 0.265 & 633 & 106,394 & 21,727 & 570,990 & 7,893 & $5,467,310$ & 4,459 & 149,993 & 93,019 & 10,382 \\
\hline $1 \mathrm{H}-1$ & 250 & 29 Jul & 0.250 & 0.290 & 295 & 109,612 & 23,150 & 598,106 & 6,155 & $5,340,919$ & 3,428 & 113,003 & 87,689 & 9,772 \\
\hline $1 \mathrm{H}-1$ & 275 & 29 Jul & 0.275 & 0.315 & 165 & 79,464 & 20,977 & 557,697 & 6,094 & $6,125,817$ & 4,628 & 215,611 & 96,548 & 10,461 \\
\hline $1 \mathrm{H}-1$ & 300 & 29 Jul & 0.300 & 0.340 & 262 & 57,496 & 21,091 & 578,414 & 6,547 & $6,161,687$ & 4,261 & 192,678 & 92,263 & 10,614 \\
\hline $1 \mathrm{H}-1$ & 325 & 29 Jul & 0.325 & 0.365 & 397 & 55,628 & 23,413 & 622,942 & 6,987 & $5,875,783$ & 5,078 & 45,705 & 87,897 & 9,471 \\
\hline $1 \mathrm{H}-1$ & 350 & $29 \mathrm{Jul}$ & 0.350 & 0.390 & 611 & 63,358 & 21,954 & 591,906 & 7,383 & $6,150,193$ & 4,384 & 40,378 & 91,854 & 10,186 \\
\hline $1 \mathrm{H}-1$ & 375 & $29 \mathrm{Jul}$ & 0.375 & 0.415 & 448 & 59,072 & 21,785 & 612,824 & 5,672 & $5,821,063$ & 4,437 & 30,007 & 78,209 & 8,369 \\
\hline $1 \mathrm{H}-1$ & 400 & 29 Jul & 0.400 & 0.440 & 526 & 56,740 & 22,097 & 612,332 & 6,277 & $5,775,173$ & 4,264 & 30,953 & 79,233 & 8,851 \\
\hline $1 \mathrm{H}-1$ & 425 & 29 Jul & 0.425 & 0.465 & 515 & 59,134 & 21,841 & 627,211 & 5,879 & $6,045,124$ & 4,183 & 33,817 & 79,555 & 8,692 \\
\hline $1 \mathrm{H}-1$ & 450 & 29 Jul & 0.450 & 0.490 & 276 & 49,103 & 23,257 & 640,795 & 6,365 & $5,620,226$ & 3,963 & 31,207 & 70,631 & 8,189 \\
\hline $1 \mathrm{H}-1$ & 475 & 29 Jul & 0.475 & 0.515 & 474 & 40,776 & 24,811 & 707,600 & 5,090 & $5,065,880$ & 3,154 & 36,204 & 68,976 & 8,088 \\
\hline $1 \mathrm{H}-1$ & 500 & 29 Jul & 0.500 & 0.540 & 412 & 42,209 & 26,338 & 718,848 & 6,063 & $5,287,877$ & 3,773 & 31,918 & 75,054 & 8,452 \\
\hline $1 \mathrm{H}-1$ & 525 & 29 Jul & 0.525 & 0.565 & 250 & 43,704 & 23,015 & 668,223 & 5,078 & $5,400,234$ & 2,662 & 26,998 & 69,963 & 7,515 \\
\hline $1 \mathrm{H}-1$ & 550 & $29 \mathrm{Jul}$ & 0.550 & 0.590 & 344 & 65,255 & 22,762 & 656,185 & 5,510 & $5,924,826$ & 3,782 & 19,522 & 70,260 & 7,402 \\
\hline $1 \mathrm{H}-1$ & 575 & 29 Jul & 0.575 & 0.615 & 508 & 55,367 & 23,779 & 649,213 & 4,293 & $5,533,030$ & 3,150 & 22,116 & 69,223 & 7,482 \\
\hline $1 \mathrm{H}-1$ & 600 & 29 Jul & 0.600 & 0.640 & 292 & 54,203 & 22,318 & 622,895 & 2,539 & $5,330,983$ & 2,973 & 15,466 & 62,797 & 5,850 \\
\hline $1 \mathrm{H}-1$ & 625 & $29 \mathrm{Jul}$ & 0.625 & 0.665 & 551 & 69,327 & 21,772 & 604,146 & 3,248 & $6,307,831$ & 2,841 & 21,300 & 70,224 & 6,139 \\
\hline $1 \mathrm{H}-1$ & 650 & 29 Jul & 0.650 & 0.690 & 253 & 67,414 & 24,065 & 655,523 & 3,049 & $5,421,827$ & 2,376 & 17,031 & 55,641 & 5,944 \\
\hline $1 \mathrm{H}-1$ & 675 & 29 Jul & 0.675 & 0.715 & 360 & 57,532 & 22,015 & 617,115 & 4,382 & $5,934,125$ & 2,834 & 56,416 & 67,879 & 6,751 \\
\hline $1 \mathrm{H}-1$ & 700 & 29 Jul & 0.700 & 0.740 & 306 & 57,916 & 21,199 & 611,161 & 3,128 & $5,851,201$ & 2,740 & 40,821 & 67,904 & 6,692 \\
\hline $1 \mathrm{H}-1$ & 725 & 29 Jul & 0.725 & 0.765 & 620 & 62,461 & 20,340 & 571,223 & 4,724 & $6,091,732$ & 2,762 & 50,170 & 66,785 & 6,742 \\
\hline $1 \mathrm{H}-1$ & 750 & 29 Jul & 0.750 & 0.790 & 261 & 44,115 & 20,660 & 629,893 & 2,852 & $5,095,266$ & 1,733 & 34,887 & 59,237 & 7,112 \\
\hline $1 \mathrm{H}-1$ & 775 & 29 Jul & 0.775 & 0.815 & 325 & 49,114 & 18,640 & 574,651 & 1,430 & $5,803,417$ & 1,901 & 26,677 & 62,104 & 6,532 \\
\hline $1 \mathrm{H}-1$ & 800 & 29 Jul & 0.800 & 0.840 & 266 & 54,097 & 20,076 & 636,584 & 2,043 & $5,640,361$ & 1,876 & 30,073 & 67,662 & 6,624 \\
\hline $1 \mathrm{H}-1$ & 825 & $29 \mathrm{Jul}$ & 0.825 & 0.865 & 110 & 48,609 & 22,560 & 622,630 & 1,103 & $4,894,580$ & 2,253 & 39,294 & 59,105 & 6,967 \\
\hline $1 \mathrm{H}-1$ & 850 & 29 Jul & 0.850 & 0.890 & 263 & 70,631 & 22,439 & 616,785 & 3,341 & $5,000,849$ & 2,508 & 57,592 & 65,050 & 6,810 \\
\hline $1 \mathrm{H}-1$ & 875 & 29 Jul & 0.875 & 0.915 & 646 & 77,556 & 21,123 & 596,848 & 4,157 & $6,044,992$ & 3,010 & 33,031 & 76,096 & 6,822 \\
\hline $1 \mathrm{H}-1$ & 900 & 29 Jul & 0.900 & 0.940 & 337 & 62,267 & 20,490 & 605,333 & 882 & $4,777,876$ & 3,988 & 35,152 & 62,327 & 6,855 \\
\hline $1 \mathrm{H}-1$ & 925 & 29 Jul & 0.925 & 0.965 & 47 & 58,742 & 24,689 & 670,855 & 3,681 & $4,745,994$ & 1,546 & 26,640 & 63,732 & 6,243 \\
\hline $1 \mathrm{H}-1$ & 950 & $29 \mathrm{Jul}$ & 0.950 & 0.990 & 400 & 73,213 & 22,566 & 620,576 & 3,830 & $4,834,842$ & 1,273 & 22,303 & 71,860 & 7,165 \\
\hline $1 \mathrm{H}-1$ & 975 & $29 \mathrm{Jul}$ & 0.975 & 1.015 & 350 & 73,781 & 21,954 & 611,750 & 5,517 & $5,119,603$ & 2,019 & 23,729 & 70,781 & 7,286 \\
\hline $1 \mathrm{H}-1$ & 1,000 & $29 \mathrm{Jul}$ & 1.000 & 1.040 & 610 & 89,812 & 19,612 & 539,125 & 4,517 & $5,907,522$ & 3,215 & 26,194 & 73,703 & 6,210 \\
\hline $1 \mathrm{H}-1$ & 1,025 & 29 Jul & 1.025 & 1.065 & 544 & 81,524 & 20,710 & 568,607 & 5,489 & $5,312,686$ & 2,855 & 37,549 & 69,539 & 6,541 \\
\hline $1 \mathrm{H}-1$ & 1,050 & $29 \mathrm{Jul}$ & 1.050 & 1.090 & 171 & 60,647 & 22,569 & 607,420 & 3,570 & $4,806,630$ & 2,427 & 56,226 & 67,783 & 6,657 \\
\hline $1 \mathrm{H}-1$ & 1,075 & $29 \mathrm{Jul}$ & 1.075 & 1.115 & -56 & 54,263 & 24,678 & 616,152 & 6,011 & $3,942,852$ & 3,024 & 58,016 & 73,135 & 6,530 \\
\hline
\end{tabular}

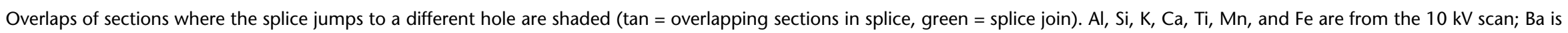


Table T2. Spliced NMS, Hole U1338A. (Continued on next two pages.)

\begin{tabular}{|c|c|c|c|c|c|c|c|c|c|c|c|c|}
\hline $\begin{array}{l}\text { Core, } \\
\text { section }\end{array}$ & $\begin{array}{c}\text { Depth } \\
\text { in section } \\
(\mathrm{mm})\end{array}$ & $\begin{array}{c}\text { Measurement } \\
\text { date } \\
(2009)\end{array}$ & $\begin{array}{c}\text { Depth } \\
\text { (mbsf/ } \\
\text { CSF-A } \\
{[\mathrm{m}] \text { ) }}\end{array}$ & $\begin{array}{c}\text { Depth } \\
\text { (mcd/ } \\
\text { CCSF-A } \\
[\mathrm{m}])\end{array}$ & $\begin{array}{l}\text { Raw } \\
\text { component } \\
\text { sum (\%) }\end{array}$ & Al area & $\begin{array}{l}\text { Al median- } \\
\text { scale }\end{array}$ & $\begin{array}{l}\mathrm{Al}_{2} \mathrm{O}_{3} \\
\mathrm{NMS}\end{array}$ & Si area & $\begin{array}{l}\text { Si median- } \\
\text { scale }\end{array}$ & $\begin{array}{l}\mathrm{SiO}_{2} \\
\mathrm{NMS}\end{array}$ & $\mathrm{S}$ area \\
\hline \multicolumn{13}{|c|}{ 321-U1338A- } \\
\hline $1 \mathrm{H}-1$ & 25 & $29 \mathrm{Jul}$ & 0.025 & 0.065 & 32.443 & -196 & 0.000 & 0.000 & 31,096 & 3.04 & 9.38 & 13,457 \\
\hline $1 \mathrm{H}-1$ & 50 & $29 \mathrm{Jul}$ & 0.050 & 0.090 & 42.712 & -98 & 0.000 & 0.000 & 39,489 & 3.86 & 9.04 & 27,680 \\
\hline $1 \mathrm{H}-1$ & 75 & $29 \mathrm{Jul}$ & 0.075 & 0.115 & 56.755 & 31 & 0.008 & 0.014 & 54,291 & 5.31 & 9.36 & 25,702 \\
\hline $1 \mathrm{H}-1$ & 100 & $29 \mathrm{Jul}$ & 0.100 & 0.140 & 56.684 & -64 & 0.000 & 0.000 & 58,567 & 5.73 & 10.11 & 25,225 \\
\hline $1 \mathrm{H}-1$ & 125 & $29 \mathrm{Jul}$ & 0.125 & 0.165 & 79.203 & 261 & 0.069 & 0.087 & 74,200 & 7.26 & 9.16 & 21,599 \\
\hline $1 \mathrm{H}-1$ & 150 & $29 \mathrm{Jul}$ & 0.150 & 0.190 & 80.580 & 474 & 0.125 & 0.155 & 99,029 & 9.69 & 12.02 & 21,387 \\
\hline $1 \mathrm{H}-1$ & 175 & $29 \mathrm{Jul}$ & 0.175 & 0.215 & 80.788 & 294 & 0.078 & 0.096 & 79,255 & 7.75 & 9.60 & 22,413 \\
\hline $1 \mathrm{H}-1$ & 200 & $29 \mathrm{Jul}$ & 0.200 & 0.240 & 78.611 & 168 & 0.044 & 0.056 & 78,416 & 7.67 & 9.76 & 24,243 \\
\hline $1 \mathrm{H}-1$ & 225 & $29 \mathrm{Jul}$ & 0.225 & 0.265 & 81.680 & 633 & 0.167 & 0.205 & 106,394 & 10.41 & 12.74 & 21,727 \\
\hline $1 \mathrm{H}-1$ & 250 & $29 \mathrm{Jul}$ & 0.250 & 0.290 & 79.923 & 295 & 0.078 & 0.098 & 109,612 & 10.72 & 13.42 & 23,150 \\
\hline $1 \mathrm{H}-1$ & 275 & $29 \mathrm{Jul}$ & 0.275 & 0.315 & 87.682 & 165 & 0.044 & 0.050 & 79,464 & 7.77 & 8.87 & 20,977 \\
\hline $1 \mathrm{H}-1$ & 300 & $29 \mathrm{Jul}$ & 0.300 & 0.340 & 85.808 & 262 & 0.069 & 0.081 & 57,496 & 5.62 & 6.55 & 21,091 \\
\hline $1 \mathrm{H}-1$ & 325 & $29 \mathrm{Jul}$ & 0.325 & 0.365 & 80.863 & 397 & 0.105 & 0.130 & 55,628 & 5.44 & 6.73 & 23,413 \\
\hline $1 \mathrm{H}-1$ & 350 & $29 \mathrm{Jul}$ & 0.350 & 0.390 & 85.145 & 611 & 0.161 & 0.190 & 63,358 & 6.20 & 7.28 & 21,954 \\
\hline $1 \mathrm{H}-1$ & 375 & $29 \mathrm{Jul}$ & 0.375 & 0.415 & 80.249 & 448 & 0.118 & 0.148 & 59,072 & 5.78 & 7.20 & 21,785 \\
\hline $1 \mathrm{H}-1$ & 400 & $29 \mathrm{Jul}$ & 0.400 & 0.440 & 79.514 & 526 & 0.139 & 0.175 & 56,740 & 5.55 & 6.98 & 22,097 \\
\hline $1 \mathrm{H}-1$ & 425 & $29 \mathrm{Jul}$ & 0.425 & 0.465 & 83.140 & 515 & 0.136 & 0.164 & 59,134 & 5.78 & 6.96 & 21,841 \\
\hline $1 \mathrm{H}-1$ & 450 & $29 \mathrm{Jul}$ & 0.450 & 0.490 & 76.661 & 276 & 0.073 & 0.095 & 49,103 & 4.80 & 6.27 & 23,257 \\
\hline $1 \mathrm{H}-1$ & 475 & $29 \mathrm{Jul}$ & 0.475 & 0.515 & 68.939 & 474 & 0.125 & 0.182 & 40,776 & 3.99 & 5.79 & 24,811 \\
\hline $1 \mathrm{H}-1$ & 500 & $29 \mathrm{Jul}$ & 0.500 & 0.540 & 71.903 & 412 & 0.109 & 0.151 & 42,209 & 4.13 & 5.74 & 26,338 \\
\hline $1 \mathrm{H}-1$ & 525 & $29 \mathrm{Jul}$ & 0.525 & 0.565 & 73.274 & 250 & 0.066 & 0.090 & 43,704 & 4.28 & 5.83 & 23,015 \\
\hline $1 \mathrm{H}-1$ & 550 & $29 \mathrm{Jul}$ & 0.550 & 0.590 & 81.936 & 344 & 0.091 & 0.111 & 65,255 & 6.38 & 7.79 & 22,762 \\
\hline $1 \mathrm{H}-1$ & 575 & $29 \mathrm{Jul}$ & 0.575 & 0.615 & 76.084 & 508 & 0.134 & 0.176 & 55,367 & 5.42 & 7.12 & 23,779 \\
\hline $1 \mathrm{H}-1$ & 600 & $29 \mathrm{Jul}$ & 0.600 & 0.640 & 73.171 & 292 & 0.077 & 0.105 & 54,203 & 5.30 & 7.25 & 22,318 \\
\hline $1 \mathrm{H}-1$ & 625 & $29 \mathrm{Jul}$ & 0.625 & 0.665 & 87.105 & 551 & 0.146 & 0.167 & 69,327 & 6.78 & 7.79 & 21,772 \\
\hline $1 \mathrm{H}-1$ & 650 & $29 \mathrm{Jul}$ & 0.650 & 0.690 & 75.556 & 253 & 0.067 & 0.088 & 67,414 & 6.59 & 8.73 & 24,065 \\
\hline $1 \mathrm{H}-1$ & 675 & $29 \mathrm{Jul}$ & 0.675 & 0.715 & 81.516 & 360 & 0.095 & 0.117 & 57,532 & 5.63 & 6.90 & 22,015 \\
\hline $1 \mathrm{H}-1$ & 700 & $29 \mathrm{Jul}$ & 0.700 & 0.740 & 80.348 & 306 & 0.081 & 0.101 & 57,916 & 5.67 & 7.05 & 21,199 \\
\hline $1 \mathrm{H}-1$ & 725 & $29 \mathrm{Jul}$ & 0.725 & 0.765 & 83.993 & 620 & 0.164 & 0.195 & 62,461 & 6.11 & 7.27 & 20,340 \\
\hline $1 \mathrm{H}-1$ & 750 & $29 \mathrm{Jul}$ & 0.750 & 0.790 & 69.393 & 261 & 0.069 & 0.099 & 44,115 & 4.32 & 6.22 & 20,660 \\
\hline $1 \mathrm{H}-1$ & 775 & $29 \mathrm{Jul}$ & 0.775 & 0.815 & 78.685 & 325 & 0.086 & 0.109 & 49,114 & 4.80 & 6.11 & 18,640 \\
\hline $1 \mathrm{H}-1$ & 800 & $29 \mathrm{Jul}$ & 0.800 & 0.840 & 77.206 & 266 & 0.070 & 0.091 & 54,097 & 5.29 & 6.85 & 20,076 \\
\hline $1 \mathrm{H}-1$ & 825 & $29 \mathrm{Jul}$ & 0.825 & 0.865 & 67.264 & 110 & 0.029 & 0.043 & 48,609 & 4.75 & 7.07 & 22,560 \\
\hline $1 \mathrm{H}-1$ & 850 & $29 \mathrm{Jul}$ & 0.850 & 0.890 & 71.032 & 263 & 0.070 & 0.098 & 70,631 & 6.91 & 9.73 & 22,439 \\
\hline $1 \mathrm{H}-1$ & 875 & $29 \mathrm{Jul}$ & 0.875 & 0.915 & 84.829 & 646 & 0.171 & 0.201 & 77,556 & 7.59 & 8.94 & 21,123 \\
\hline $1 \mathrm{H}-1$ & 900 & $29 \mathrm{Jul}$ & 0.900 & 0.940 & 67.185 & 337 & 0.089 & 0.133 & 62,267 & 6.09 & 9.07 & 20,490 \\
\hline $1 \mathrm{H}-1$ & 925 & $29 \mathrm{Jul}$ & 0.925 & 0.965 & 66.351 & 47 & 0.012 & 0.019 & 58,742 & 5.75 & 8.66 & 24,689 \\
\hline $1 \mathrm{H}-1$ & 950 & $29 \mathrm{Jul}$ & 0.950 & 0.990 & 69.048 & 400 & 0.106 & 0.153 & 73,213 & 7.16 & 10.37 & 22,566 \\
\hline $1 \mathrm{H}-1$ & 975 & $29 \mathrm{Jul}$ & 0.975 & 1.015 & 72.707 & 350 & 0.092 & 0.127 & 73,781 & 7.22 & 9.93 & 21,954 \\
\hline $1 \mathrm{H}-1$ & 1,000 & $29 \mathrm{Jul}$ & 1.000 & 1.040 & 84.207 & 610 & 0.161 & 0.191 & 89,812 & 8.79 & 10.43 & 19,612 \\
\hline $1 \mathrm{H}-1$ & 1,025 & $29 \mathrm{Jul}$ & 1.025 & 1.065 & 76.006 & 544 & 0.144 & 0.189 & 81,524 & 7.97 & 10.49 & 20,710 \\
\hline $1 \mathrm{H}-1$ & 1,050 & $29 \mathrm{Jul}$ & 1.050 & 1.090 & 67.609 & 171 & 0.045 & 0.067 & 60,647 & 5.93 & 8.77 & 22,569 \\
\hline $1 \mathrm{H}-1$ & 1,075 & $29 \mathrm{Jul}$ & 1.075 & 1.115 & 56.223 & -56 & 0.000 & 0.000 & 54,263 & 5.31 & 9.44 & 24,678 \\
\hline $1 \mathrm{H}-1$ & 1,100 & $29 \mathrm{Jul}$ & 1.100 & 1.140 & 45.720 & -127 & 0.000 & 0.000 & 45,904 & 4.49 & 9.82 & 24,823 \\
\hline $1 \mathrm{H}-1$ & 1,125 & $29 \mathrm{Jul}$ & 1.125 & 1.165 & 62.460 & 4 & 0.001 & 0.002 & 79,860 & 7.81 & 12.51 & 24,486 \\
\hline $1 \mathrm{H}-1$ & 1,150 & $29 \mathrm{Jul}$ & 1.150 & 1.190 & 48.900 & 117 & 0.031 & 0.063 & 56,342 & 5.51 & 11.27 & 20,845 \\
\hline $1 \mathrm{H}-1$ & 1,175 & $29 \mathrm{Jul}$ & 1.175 & 1.215 & 54.956 & 182 & 0.048 & 0.088 & 79,743 & 7.80 & 14.19 & 30,302 \\
\hline $1 \mathrm{H}-1$ & 1,200 & $29 \mathrm{Jul}$ & 1.200 & 1.240 & 49.787 & 195 & 0.052 & 0.104 & 71,091 & 6.95 & 13.97 & 31,844 \\
\hline $1 \mathrm{H}-1$ & 1,225 & $29 \mathrm{Jul}$ & 1.225 & 1.265 & 54.761 & 104 & 0.027 & 0.050 & 74,635 & 7.30 & 13.33 & 25,977 \\
\hline $1 \mathrm{H}-1$ & 1,250 & $29 \mathrm{Jul}$ & 1.250 & 1.290 & 35.408 & -331 & 0.000 & 0.000 & 45,485 & 4.45 & 12.57 & 31,332 \\
\hline $1 \mathrm{H}-1$ & 1,275 & $29 \mathrm{Jul}$ & 1.275 & 1.315 & 45.565 & 430 & 0.114 & 0.249 & 107,283 & 10.49 & 23.03 & 35,849 \\
\hline $1 \mathrm{H}-1$ & 1,300 & $29 \mathrm{Jul}$ & 1.300 & 1.340 & 26.109 & -169 & 0.000 & 0.000 & 37,894 & 3.71 & 14.20 & 33,187 \\
\hline $1 \mathrm{H}-1$ & 1,325 & 29 Jul & 1.325 & 1.365 & 33.589 & -38 & 0.000 & 0.000 & 58,964 & 5.77 & 17.17 & 29,457 \\
\hline $1 \mathrm{H}-1$ & 1,350 & $29 \mathrm{Jul}$ & 1.350 & 1.390 & 39.756 & -262 & 0.000 & 0.000 & 51,970 & 5.08 & 12.79 & 34,524 \\
\hline $1 \mathrm{H}-1$ & 1,375 & 29 Jul & 1.375 & 1.415 & 35.315 & -332 & 0.000 & 0.000 & 54,052 & 5.29 & 14.97 & 33,412 \\
\hline $1 \mathrm{H}-1$ & 1,400 & $29 \mathrm{Jul}$ & 1.400 & 1.440 & 43.730 & -37 & 0.000 & 0.000 & 72,746 & 7.12 & 16.27 & 31,160 \\
\hline $1 \mathrm{H}-1$ & 1,425 & $29 \mathrm{Jul}$ & 1.425 & 1.465 & 46.225 & 336 & 0.089 & 0.192 & 88,308 & 8.64 & 18.69 & 27,293 \\
\hline $1 \mathrm{H}-2$ & 25 & $29 \mathrm{Jul}$ & 1.525 & 1.565 & 29.196 & -146 & 0.000 & 0.000 & 59,620 & 5.83 & 19.98 & 26,096 \\
\hline $1 \mathrm{H}-2$ & 50 & 29 Jul & 1.550 & 1.590 & 34.848 & -349 & 0.000 & 0.000 & 42,906 & 4.20 & 12.04 & 32,993 \\
\hline $1 \mathrm{H}-2$ & 75 & $29 \mathrm{Jul}$ & 1.575 & 1.615 & 27.605 & -272 & 0.000 & 0.000 & 26,424 & 2.58 & 9.36 & 32,931 \\
\hline $1 \mathrm{H}-2$ & 100 & $29 \mathrm{Jul}$ & 1.600 & 1.640 & 26.098 & -251 & 0.000 & 0.000 & 30,607 & 2.99 & 11.47 & 32,628 \\
\hline $1 \mathrm{H}-2$ & 125 & $29 \mathrm{Jul}$ & 1.625 & 1.665 & 24.268 & -176 & 0.000 & 0.000 & 35,143 & 3.44 & 14.17 & 30,839 \\
\hline
\end{tabular}

$\mathrm{Al}, \mathrm{Si}, \mathrm{K}, \mathrm{Ca}, \mathrm{Ti}, \mathrm{Mn}$, and $\mathrm{Fe}$, are from the $10 \mathrm{kV}$ scan; $\mathrm{Ba}$ is from the $50 \mathrm{kV}$ scan. Only a portion of this table appears here. The complete table is available in ASCII and in Microsoft Excel format (see NMSSPL.XLS in XRF in "Supplementary material"). 
Table T2 (continued). (Continued on next page.)

\begin{tabular}{|c|c|c|c|c|c|c|c|c|c|c|c|c|c|}
\hline $\begin{array}{l}\text { Core, } \\
\text { section }\end{array}$ & $\begin{array}{l}\text { Depth } \\
\text { in section } \\
(\mathrm{mm})\end{array}$ & $\mathrm{Cl}$ area & $\mathrm{K}$ area & $\begin{array}{l}\mathrm{K} \text { median- } \\
\text { scale }\end{array}$ & $\begin{array}{l}\mathrm{K}_{2} \mathrm{O} \\
\mathrm{NMS}\end{array}$ & Ca area & $\begin{array}{l}\text { Ca median- } \\
\text { scale }\end{array}$ & $\begin{array}{l}\mathrm{CaCO}_{3} \\
\mathrm{NMS}\end{array}$ & Ti area & $\begin{array}{l}\text { Ti median- } \\
\text { scale }\end{array}$ & $\begin{array}{l}\mathrm{TiO}_{2} \\
\mathrm{NMS}\end{array}$ & Mn area & $\begin{array}{c}\text { Mn } \\
\text { median- } \\
\text { scale }\end{array}$ \\
\hline \multicolumn{14}{|c|}{ 321-U1338A- } \\
\hline $1 \mathrm{H}-1$ & 25 & 293,730 & $(1,343)$ & 0.000 & 0.000 & $2,258,381$ & 28.32 & 87.28 & 1,320 & 0.0011 & 0.0033 & 65,711 & 0.511 \\
\hline $1 \mathrm{H}-1$ & 50 & 771,065 & 7,437 & 0.172 & 0.403 & $2,914,316$ & 36.54 & 85.55 & 3,180 & 0.0026 & 0.0060 & 114,737 & 0.893 \\
\hline $1 \mathrm{H}-1$ & 75 & 670,383 & 7,910 & 0.183 & 0.323 & $3,917,938$ & 49.12 & 86.56 & 4,312 & 0.0035 & 0.0061 & 120,200 & 0.935 \\
\hline $1 \mathrm{H}-1$ & 100 & 649,819 & 8,859 & 0.205 & 0.362 & $3,879,549$ & 48.64 & 85.82 & 4,132 & 0.0033 & 0.0059 & 120,278 & 0.936 \\
\hline $1 \mathrm{H}-1$ & 125 & 559,320 & 8,642 & 0.200 & 0.253 & $5,529,714$ & 69.33 & 87.54 & 5,545 & 0.0045 & 0.0056 & 150,111 & 1.168 \\
\hline $1 \mathrm{H}-1$ & 150 & 577,860 & 9,292 & 0.215 & 0.267 & $5,459,765$ & 68.46 & 84.95 & 4,785 & 0.0038 & 0.0048 & 116,935 & 0.910 \\
\hline $1 \mathrm{H}-1$ & 175 & 611,799 & 7,209 & 0.167 & 0.207 & $5,622,123$ & 70.49 & 87.26 & 5,203 & 0.0042 & 0.0052 & 148,228 & 1.153 \\
\hline $1 \mathrm{H}-1$ & 200 & 606,554 & 7,054 & 0.163 & 0.208 & $5,460,881$ & 68.47 & 87.10 & 5,675 & 0.0046 & 0.0058 & 143,363 & 1.115 \\
\hline $1 \mathrm{H}-1$ & 225 & 570,990 & 7,893 & 0.183 & 0.224 & $5,467,310$ & 68.55 & 83.93 & 4,459 & 0.0036 & 0.0044 & 149,993 & 1.167 \\
\hline $1 \mathrm{H}-1$ & 250 & 598,106 & 6,155 & 0.143 & 0.178 & $5,340,919$ & 66.97 & 83.79 & 3,428 & 0.0028 & 0.0034 & 113,003 & 0.879 \\
\hline $1 \mathrm{H}-1$ & 275 & 557,697 & 6,094 & 0.141 & 0.161 & $6,125,817$ & 76.81 & 87.60 & 4,628 & 0.0037 & 0.0042 & 215,611 & 1.678 \\
\hline $1 \mathrm{H}-1$ & 300 & 578,414 & 6,547 & 0.152 & 0.177 & $6,161,687$ & 77.26 & 90.04 & 4,261 & 0.0034 & 0.0040 & 192,678 & 1.499 \\
\hline $1 \mathrm{H}-1$ & 325 & 622,942 & 6,987 & 0.162 & 0.200 & $5,875,783$ & 73.67 & 91.11 & 5,078 & 0.0041 & 0.0050 & 45,705 & 0.356 \\
\hline $1 \mathrm{H}-1$ & 350 & 591,906 & 7,383 & 0.171 & 0.201 & $6,150,193$ & 77.11 & 90.57 & 4,384 & 0.0035 & 0.0041 & 40,378 & 0.314 \\
\hline $1 \mathrm{H}-1$ & 375 & 612,824 & 5,672 & 0.131 & 0.164 & $5,821,063$ & 72.99 & 90.95 & 4,437 & 0.0036 & 0.0044 & 30,007 & 0.233 \\
\hline $1 \mathrm{H}-1$ & 400 & 612,332 & 6,277 & 0.145 & 0.183 & $5,775,173$ & 72.41 & 91.07 & 4,264 & 0.0034 & 0.0043 & 30,953 & 0.241 \\
\hline $1 \mathrm{H}-1$ & 425 & 627,211 & 5,879 & 0.136 & 0.164 & $6,045,124$ & 75.80 & 91.17 & 4,183 & 0.0034 & 0.0040 & 33,817 & 0.263 \\
\hline $1 \mathrm{H}-1$ & 450 & 640,795 & 6,365 & 0.147 & 0.192 & $5,620,226$ & 70.47 & 91.92 & 3,963 & 0.0032 & 0.0042 & 31,207 & 0.243 \\
\hline $1 \mathrm{H}-1$ & 475 & 707,600 & 5,090 & 0.118 & 0.171 & $5,065,880$ & 63.52 & 92.14 & 3,154 & 0.0025 & 0.0037 & 36,204 & 0.282 \\
\hline $1 \mathrm{H}-1$ & 500 & 718,848 & 6,063 & 0.140 & 0.195 & $5,287,877$ & 66.30 & 92.21 & 3,773 & 0.0030 & 0.0042 & 31,918 & 0.248 \\
\hline $1 \mathrm{H}-1$ & 525 & 668,223 & 5,078 & 0.118 & 0.160 & $5,400,234$ & 67.71 & 92.41 & 2,662 & 0.0021 & 0.0029 & 26,998 & 0.210 \\
\hline $1 \mathrm{H}-1$ & 550 & 656,185 & 5,510 & 0.128 & 0.156 & $5,924,826$ & 74.29 & 90.67 & 3,782 & 0.0030 & 0.0037 & 19,522 & 0.152 \\
\hline $1 \mathrm{H}-1$ & 575 & 649,213 & 4,293 & 0.099 & 0.131 & $5,533,030$ & 69.38 & 91.18 & 3,150 & 0.0025 & 0.0033 & 22,116 & 0.172 \\
\hline $1 \mathrm{H}-1$ & 600 & 622,895 & 2,539 & 0.059 & 0.080 & $5,330,983$ & 66.84 & 91.35 & 2,973 & 0.0024 & 0.0033 & 15,466 & 0.120 \\
\hline $1 \mathrm{H}-1$ & 625 & 604,146 & 3,248 & 0.075 & 0.086 & $6,307,831$ & 79.09 & 90.80 & 2,841 & 0.0023 & 0.0026 & 21,300 & 0.166 \\
\hline $1 \mathrm{H}-1$ & 650 & 655,523 & 3,049 & 0.071 & 0.093 & $5,421,827$ & 67.98 & 89.97 & 2,376 & 0.0019 & 0.0025 & 17,031 & 0.133 \\
\hline $1 \mathrm{H}-1$ & 675 & 617,115 & 4,382 & 0.101 & 0.124 & $5,934,125$ & 74.40 & 91.28 & 2,834 & 0.0023 & 0.0028 & 56,416 & 0.439 \\
\hline $1 \mathrm{H}-1$ & 700 & 611,161 & 3,128 & 0.072 & 0.090 & $5,851,201$ & 73.36 & 91.31 & 2,740 & 0.0022 & 0.0027 & 40,821 & 0.318 \\
\hline $1 \mathrm{H}-1$ & 725 & 571,223 & 4,724 & 0.109 & 0.130 & $6,091,732$ & 76.38 & 90.94 & 2,762 & 0.0022 & 0.0026 & 50,170 & 0.390 \\
\hline $1 \mathrm{H}-1$ & 750 & 629,893 & 2,852 & 0.066 & 0.095 & $5,095,266$ & 63.89 & 92.06 & 1,733 & 0.0014 & 0.0020 & 34,887 & 0.271 \\
\hline $1 \mathrm{H}-1$ & 775 & 574,651 & 1,430 & 0.033 & 0.042 & $5,803,417$ & 72.77 & 92.48 & 1,901 & 0.0015 & 0.0019 & 26,677 & 0.208 \\
\hline $1 \mathrm{H}-1$ & 800 & 636,584 & 2,043 & 0.047 & 0.061 & $5,640,361$ & 70.72 & 91.60 & 1,876 & 0.0015 & 0.0020 & 30,073 & 0.234 \\
\hline $1 \mathrm{H}-1$ & 825 & 622,630 & 1,103 & 0.026 & 0.038 & $4,894,580$ & 61.37 & 91.24 & 2,253 & 0.0018 & 0.0027 & 39,294 & 0.306 \\
\hline $1 \mathrm{H}-1$ & 850 & 616,785 & 3,341 & 0.077 & 0.109 & $5,000,849$ & 62.70 & 88.27 & 2,508 & 0.0020 & 0.0028 & 57,592 & 0.448 \\
\hline $1 \mathrm{H}-1$ & 875 & 596,848 & 4,157 & 0.096 & 0.113 & $6,044,992$ & 75.79 & 89.35 & 3,010 & 0.0024 & 0.0029 & 33,031 & 0.257 \\
\hline $1 \mathrm{H}-1$ & 900 & 605,333 & 882 & 0.020 & 0.030 & $4,777,876$ & 59.91 & 89.17 & 3,988 & 0.0032 & 0.0048 & 35,152 & 0.274 \\
\hline $1 \mathrm{H}-1$ & 925 & 670,855 & 3,681 & 0.085 & 0.128 & $4,745,994$ & 59.51 & 89.69 & 1,546 & 0.0012 & 0.0019 & 26,640 & 0.207 \\
\hline $1 \mathrm{H}-1$ & 950 & 620,576 & 3,830 & 0.089 & 0.128 & $4,834,842$ & 60.62 & 87.79 & 1,273 & 0.0010 & 0.0015 & 22,303 & 0.174 \\
\hline $1 \mathrm{H}-1$ & 975 & 611,750 & 5,517 & 0.128 & 0.176 & $5,119,603$ & 64.19 & 88.29 & 2,019 & 0.0016 & 0.0022 & 23,729 & 0.185 \\
\hline $1 \mathrm{H}-1$ & 1,000 & 539,125 & 4,517 & 0.105 & 0.124 & $5,907,522$ & 74.07 & 87.96 & 3,215 & 0.0026 & 0.0031 & 26,194 & 0.204 \\
\hline $1 \mathrm{H}-1$ & 1,025 & 568,607 & 5,489 & 0.127 & 0.167 & $5,312,686$ & 66.61 & 87.64 & 2,855 & 0.0023 & 0.0030 & 37,549 & 0.292 \\
\hline $1 \mathrm{H}-1$ & 1,050 & 607,420 & 3,570 & 0.083 & 0.122 & $4,806,630$ & 60.27 & 89.14 & 2,427 & 0.0019 & 0.0029 & 56,226 & 0.437 \\
\hline $1 \mathrm{H}-1$ & 1,075 & 616,152 & 6,011 & 0.139 & 0.248 & $3,942,852$ & 49.44 & 87.93 & 3,024 & 0.0024 & 0.0043 & 58,016 & 0.451 \\
\hline $1 \mathrm{H}-1$ & 1,100 & 668,021 & 4,239 & 0.098 & 0.215 & $3,198,341$ & 40.10 & 87.71 & 1,676 & 0.0013 & 0.0029 & 38,598 & 0.300 \\
\hline $1 \mathrm{H}-1$ & 1,125 & 621,320 & 8,279 & 0.192 & 0.307 & $4,216,530$ & 52.87 & 84.64 & 4,523 & 0.0036 & 0.0058 & 75,124 & 0.585 \\
\hline $1 \mathrm{H}-1$ & 1,150 & 510,676 & 3,212 & 0.074 & 0.152 & $3,360,285$ & 42.13 & 86.16 & 4,060 & 0.0033 & 0.0067 & 35,604 & 0.277 \\
\hline $1 \mathrm{H}-1$ & 1,175 & 724,966 & 14,248 & 0.330 & 0.600 & $3,577,836$ & 44.86 & 81.63 & 4,674 & 0.0038 & 0.0068 & 69,903 & 0.544 \\
\hline $1 \mathrm{H}-1$ & 1,200 & 721,878 & 7,842 & 0.182 & 0.365 & $3,306,120$ & 41.45 & 83.26 & 3,188 & 0.0026 & 0.0051 & 34,079 & 0.265 \\
\hline $1 \mathrm{H}-1$ & 1,225 & 643,154 & 12,751 & 0.295 & 0.539 & $3,618,646$ & 45.37 & 82.85 & 3,744 & 0.0030 & 0.0055 & 53,209 & 0.414 \\
\hline $1 \mathrm{H}-1$ & 1,250 & 753,138 & 12,815 & 0.297 & 0.838 & $2,292,403$ & 28.74 & 81.18 & 4,540 & 0.0036 & 0.0103 & 39,202 & 0.305 \\
\hline $1 \mathrm{H}-1$ & 1,275 & 770,154 & 14,936 & 0.346 & 0.759 & $2,644,121$ & 33.15 & 72.76 & 4,506 & 0.0036 & 0.0079 & 33,461 & 0.260 \\
\hline $1 \mathrm{H}-1$ & 1,300 & 805,380 & 14,758 & 0.342 & 1.309 & $1,581,744$ & 19.83 & 75.96 & 5,125 & 0.0041 & 0.0158 & 39,551 & 0.308 \\
\hline $1 \mathrm{H}-1$ & 1,325 & 755,554 & 16,924 & 0.392 & 1.167 & $1,988,632$ & 24.93 & 74.23 & 7,922 & 0.0064 & 0.0189 & 39,644 & 0.308 \\
\hline $1 \mathrm{H}-1$ & 1,350 & 814,134 & 19,003 & 0.440 & 1.107 & $2,530,553$ & 31.73 & 79.81 & 7,434 & 0.0060 & 0.0150 & 48,185 & 0.375 \\
\hline $1 \mathrm{H}-1$ & 1,375 & 795,217 & 21,032 & 0.487 & 1.379 & $2,142,968$ & 26.87 & 76.08 & 9,576 & 0.0077 & 0.0218 & 41,151 & 0.320 \\
\hline $1 \mathrm{H}-1$ & 1,400 & 758,584 & 23,438 & 0.543 & 1.241 & $2,650,436$ & 33.23 & 75.99 & 10,547 & 0.0085 & 0.0194 & 46,610 & 0.363 \\
\hline $1 \mathrm{H}-1$ & 1,425 & 586,722 & 20,293 & 0.470 & 1.017 & $2,783,249$ & 34.90 & 75.49 & 8,328 & 0.0067 & 0.0145 & 47,630 & 0.371 \\
\hline $1 \mathrm{H}-2$ & 25 & 538,343 & 18,325 & 0.424 & 1.453 & $1,571,684$ & 19.71 & 67.50 & 8,918 & 0.0072 & 0.0245 & 141,444 & 1.101 \\
\hline $1 \mathrm{H}-2$ & 50 & 787,958 & 15,936 & 0.369 & 1.059 & $2,226,434$ & 27.92 & 80.11 & 7,310 & 0.0059 & 0.0168 & 50,681 & 0.394 \\
\hline $1 \mathrm{H}-2$ & 75 & 805,494 & 12,733 & 0.295 & 1.068 & $1,770,030$ & 22.19 & 80.39 & 4,380 & 0.0035 & 0.0127 & 80,342 & 0.625 \\
\hline $1 \mathrm{H}-2$ & 100 & 784,573 & 17,289 & 0.400 & 1.534 & $1,467,440$ & 18.40 & 70.50 & 8,003 & 0.0064 & 0.0246 & 227,596 & 1.771 \\
\hline $1 \mathrm{H}-2$ & 125 & 771,104 & 14,781 & 0.342 & 1.410 & $1,343,867$ & 16.85 & 69.43 & 5,566 & 0.0045 & 0.0184 & 188,299 & 1.465 \\
\hline
\end{tabular}


Table T2 (continued).

\begin{tabular}{|c|c|c|c|c|c|c|c|c|}
\hline $\begin{array}{l}\text { Core, } \\
\text { section }\end{array}$ & $\begin{array}{l}\text { Depth } \\
\text { in section } \\
(\mathrm{mm})\end{array}$ & $\begin{array}{l}\text { MnO } \\
\text { NMS }\end{array}$ & Fe area & $\begin{array}{l}\text { Fe median- } \\
\text { scale }\end{array}$ & $\begin{array}{l}\mathrm{Fe}_{2} \mathrm{O}_{3} \\
\mathrm{NMS}\end{array}$ & $\begin{array}{l}\text { Ba area } \\
(50 \mathrm{kV} \\
\text { scan) }\end{array}$ & $\begin{array}{l}\text { Ba median- } \\
\text { scaled }\end{array}$ & $\begin{array}{l}\mathrm{BaSO}_{4} \\
\mathrm{NMS}\end{array}$ \\
\hline \multicolumn{9}{|c|}{ 321-U1338A- } \\
\hline $1 \mathrm{H}-1$ & 25 & 1.576 & 50,683 & 0.449 & 1.382 & 3,398 & 0.124 & 0.381 \\
\hline $1 \mathrm{H}-1$ & 50 & 2.090 & 90,042 & 0.797 & 1.865 & 12,199 & 0.444 & 1.040 \\
\hline $1 \mathrm{H}-1$ & 75 & 1.648 & 89,287 & 0.790 & 1.392 & 10,974 & 0.400 & 0.704 \\
\hline $1 \mathrm{H}-1$ & 100 & 1.651 & 90,977 & 0.805 & 1.420 & 9,940 & 0.362 & 0.639 \\
\hline $1 \mathrm{H}-1$ & 125 & 1.475 & 90,424 & 0.800 & 1.010 & 10,158 & 0.370 & 0.467 \\
\hline $1 \mathrm{H}-1$ & 150 & 1.129 & 94,039 & 0.832 & 1.033 & 9,623 & 0.350 & 0.435 \\
\hline $1 \mathrm{H}-1$ & 175 & 1.428 & 87,932 & 0.778 & 0.963 & 9,972 & 0.363 & 0.449 \\
\hline $1 \mathrm{H}-1$ & 200 & 1.419 & 89,331 & 0.791 & 1.006 & 9,665 & 0.352 & 0.448 \\
\hline $1 \mathrm{H}-1$ & 225 & 1.429 & 93,019 & 0.823 & 1.008 & 10,382 & 0.378 & 0.463 \\
\hline $1 \mathrm{H}-1$ & 250 & 1.100 & 87,689 & 0.776 & 0.971 & 9,772 & 0.356 & 0.445 \\
\hline $1 \mathrm{H}-1$ & 275 & 1.913 & 96,548 & 0.854 & 0.974 & 10,461 & 0.381 & 0.434 \\
\hline $1 \mathrm{H}-1$ & 300 & 1.747 & 92,263 & 0.816 & 0.951 & 10,614 & 0.386 & 0.450 \\
\hline $1 \mathrm{H}-1$ & 325 & 0.440 & 87,897 & 0.778 & 0.962 & 9,471 & 0.345 & 0.426 \\
\hline $1 \mathrm{H}-1$ & 350 & 0.369 & 91,854 & 0.813 & 0.955 & 10,186 & 0.371 & 0.436 \\
\hline $1 \mathrm{H}-1$ & 375 & 0.291 & 78,209 & 0.692 & 0.862 & 8,369 & 0.305 & 0.380 \\
\hline $1 \mathrm{H}-1$ & 400 & 0.303 & 79,233 & 0.701 & 0.882 & 8,851 & 0.322 & 0.405 \\
\hline $1 \mathrm{H}-1$ & 425 & 0.316 & 79,555 & 0.704 & 0.847 & 8,692 & 0.317 & 0.381 \\
\hline $1 \mathrm{H}-1$ & 450 & 0.317 & 70,631 & 0.625 & 0.815 & 8,189 & 0.298 & 0.389 \\
\hline $1 \mathrm{H}-1$ & 475 & 0.409 & 68,976 & 0.610 & 0.885 & 8,088 & 0.295 & 0.427 \\
\hline $1 \mathrm{H}-1$ & 500 & 0.345 & 75,054 & 0.664 & 0.924 & 8,452 & 0.308 & 0.428 \\
\hline $1 \mathrm{H}-1$ & 525 & 0.287 & 69,963 & 0.619 & 0.845 & 7,515 & 0.274 & 0.373 \\
\hline $1 \mathrm{H}-1$ & 550 & 0.185 & 70,260 & 0.622 & 0.759 & 7,402 & 0.270 & 0.329 \\
\hline $1 \mathrm{H}-1$ & 575 & 0.226 & 69,223 & 0.613 & 0.805 & 7,482 & 0.272 & 0.358 \\
\hline $1 \mathrm{H}-1$ & 600 & 0.164 & 62,797 & 0.556 & 0.759 & 5,850 & 0.213 & 0.291 \\
\hline $1 \mathrm{H}-1$ & 625 & 0.190 & 70,224 & 0.621 & 0.713 & 6,139 & 0.224 & 0.257 \\
\hline $1 \mathrm{H}-1$ & 650 & 0.175 & 55,641 & 0.492 & 0.652 & 5,944 & 0.216 & 0.286 \\
\hline $1 \mathrm{H}-1$ & 675 & 0.538 & 67,879 & 0.601 & 0.737 & 6,751 & 0.246 & 0.302 \\
\hline $1 \mathrm{H}-1$ & 700 & 0.395 & 67,904 & 0.601 & 0.748 & 6,692 & 0.244 & 0.303 \\
\hline $1 \mathrm{H}-1$ & 725 & 0.465 & 66,785 & 0.591 & 0.704 & 6,742 & 0.246 & 0.292 \\
\hline $1 \mathrm{H}-1$ & 750 & 0.391 & 59,237 & 0.524 & 0.755 & 7,112 & 0.259 & 0.373 \\
\hline $1 \mathrm{H}-1$ & 775 & 0.264 & 62,104 & 0.550 & 0.698 & 6,532 & 0.238 & 0.302 \\
\hline $1 \mathrm{H}-1$ & 800 & 0.303 & 67,662 & 0.599 & 0.776 & 6,624 & 0.241 & 0.312 \\
\hline $1 \mathrm{H}-1$ & 825 & 0.455 & 59,105 & 0.523 & 0.778 & 6,967 & 0.254 & 0.377 \\
\hline $1 \mathrm{H}-1$ & 850 & 0.631 & 65,050 & 0.576 & 0.810 & 6,810 & 0.248 & 0.349 \\
\hline $1 \mathrm{H}-1$ & 875 & 0.303 & 76,096 & 0.673 & 0.794 & 6,822 & 0.248 & 0.293 \\
\hline $1 \mathrm{H}-1$ & 900 & 0.407 & 62,327 & 0.552 & 0.821 & 6,855 & 0.250 & 0.372 \\
\hline $1 \mathrm{H}-1$ & 925 & 0.312 & 63,732 & 0.564 & 0.850 & 6,243 & 0.227 & 0.343 \\
\hline $1 \mathrm{H}-1$ & 950 & 0.251 & 71,860 & 0.636 & 0.921 & 7,165 & 0.261 & 0.378 \\
\hline $1 \mathrm{H}-1$ & 975 & 0.254 & 70,781 & 0.626 & 0.861 & 7,286 & 0.265 & 0.365 \\
\hline $1 \mathrm{H}-1$ & 1,000 & 0.242 & 73,703 & 0.652 & 0.775 & 6,210 & 0.226 & 0.269 \\
\hline $1 \mathrm{H}-1$ & 1,025 & 0.384 & 69,539 & 0.615 & 0.810 & 6,541 & 0.238 & 0.313 \\
\hline $1 \mathrm{H}-1$ & 1,050 & 0.647 & 67,783 & 0.600 & 0.887 & 6,657 & 0.242 & 0.359 \\
\hline $1 \mathrm{H}-1$ & 1,075 & 0.803 & 73,135 & 0.647 & 1.151 & 6,530 & 0.238 & 0.423 \\
\hline $1 \mathrm{H}-1$ & 1,100 & 0.657 & 53,512 & 0.474 & 1.036 & 6,996 & 0.255 & 0.557 \\
\hline $1 \mathrm{H}-1$ & 1,125 & 0.936 & 81,515 & 0.721 & 1.155 & 7,629 & 0.278 & 0.445 \\
\hline $1 \mathrm{H}-1$ & 1,150 & 0.567 & 72,320 & 0.640 & 1.309 & 6,332 & 0.231 & 0.472 \\
\hline $1 \mathrm{H}-1$ & 1,175 & 0.990 & 113,512 & 1.004 & 1.828 & 10,023 & 0.365 & 0.664 \\
\hline $1 \mathrm{H}-1$ & 1,200 & 0.533 & 66,715 & 0.590 & 1.186 & 7,926 & 0.289 & 0.580 \\
\hline $1 \mathrm{H}-1$ & 1,225 & 0.756 & 111,562 & 0.987 & 1.803 & 9,933 & 0.362 & 0.660 \\
\hline $1 \mathrm{H}-1$ & 1,250 & 0.861 & 127,247 & 1.126 & 3.180 & 13,312 & 0.485 & 1.369 \\
\hline $1 \mathrm{H}-1$ & 1,275 & 0.571 & 104,438 & 0.924 & 2.028 & 7,418 & 0.270 & 0.593 \\
\hline $1 \mathrm{H}-1$ & 1,300 & 1.179 & 148,491 & 1.314 & 5.033 & 16,535 & 0.602 & 2.306 \\
\hline $1 \mathrm{H}-1$ & 1,325 & 0.918 & 176,752 & 1.564 & 4.657 & 16,931 & 0.617 & 1.835 \\
\hline $1 \mathrm{H}-1$ & 1,350 & 0.943 & 179,690 & 1.590 & 4.000 & 14,622 & 0.532 & 1.339 \\
\hline $1 \mathrm{H}-1$ & 1,375 & 0.907 & 198,901 & 1.760 & 4.984 & 16,031 & 0.584 & 1.653 \\
\hline $1 \mathrm{H}-1$ & 1,400 & 0.829 & 210,526 & 1.863 & 4.260 & 16,623 & 0.605 & 1.384 \\
\hline $1 \mathrm{H}-1$ & 1,425 & 0.802 & 153,476 & 1.358 & 2.938 & 10,865 & 0.396 & 0.856 \\
\hline $1 \mathrm{H}-2$ & 25 & 3.770 & 190,726 & 1.688 & 5.781 & 12,023 & 0.438 & 1.500 \\
\hline $1 \mathrm{H}-2$ & 50 & 1.132 & 163,752 & 1.449 & 4.158 & 14,198 & 0.517 & 1.484 \\
\hline $1 \mathrm{H}-2$ & 75 & 2.265 & 155,479 & 1.376 & 4.984 & 14,498 & 0.528 & 1.912 \\
\hline $1 \mathrm{H}-2$ & 100 & 6.786 & 203,431 & 1.800 & 6.898 & 19,959 & 0.727 & 2.785 \\
\hline $1 \mathrm{H}-2$ & 125 & 6.037 & 179,374 & 1.587 & 6.541 & 15,976 & 0.582 & 2.397 \\
\hline
\end{tabular}

